International Journal of Public Finance
E-ISSN: $2548-0499 \quad$ DOI: $10.30927 /$ ijpf.327823
Vol./Cilt: 2 | Issue/Sayı: 1 | (2017), pp. $27-62$
journal homepage: http://dergipark.gov.tr/ijpf

\title{
Türkiye'de Maliye Alanında Yapılmış Lisansüstü Tezlerin Bibliyometrik Analizi (2003-2017)
}

\author{
The Bibliometric Analysis of The Postgraduate Theses Written on \\ Public Finance in Turkey (2003-2017)
}

Furkan BEŞEL ${ }^{1}$

\section{ARTICLE INFO}

Received: 09.06.2017

Received in revised

form: 08.08.2017

Accepted: 10.08.2017

Available online:

15.08.2017

\section{JEL classification:}

A23, $\mathrm{HO}, \mathrm{C} 25$

\section{Keywords:}

Post Graduate

Theses, Public

Finance, Document

Review Analysis

\begin{abstract}
A B S T R A C T
This study was conducted for the purpose of examining postgraduate theses in the field of public finance. Council of Higher Education's National Thesis Center database has been analyzed with the technique of examining 1714 undergraduate theses documents conducted in the "Public Finance", "Financial Law" and "Finance and Economics" departments the period of 2003-2017. Postgraduate theses are comparatively analyzed by the topics of types of thesis, distribution according to years, gender distribution of thesis authors, dissertation of thesis authors, consultant distribution, consultant title distribution, jury distribution, permission status distribution, minute distribution, partial number distribution, page number averages, the most frequently used words in the headline and abstracts, the distribution of content and methods. It is aimed that this research will lead researchers to determine the content, shape and elements of study of graduate theses to be carried out in future field of public finance.
\end{abstract}

MAKALE BíLGisi

Alındı: 09.06.2017

Gözden geçirilmiş

alındı: 08.08.2017

Kabul: 10.08 .2017

Yayın: 15.08.2017

\section{JEL Kodu:}

A23, $\mathrm{HO}, \mathrm{C} 25$

\begin{abstract}
ÖZET
Bu çalışma, maliye alanında yapılmış lisansüstü tezlerin incelenmesi amacıyla yapılmıştır. Yüksek Öğretim Kurumu Ulusal Tez Merkezi veri tabanından 2003-2017 döneminde "Maliye", "Mali Hukuk" ve "Maliye ve Ekonomi" ana bilim dallarında yapılan 1714 lisansüstü tez doküman incelemesi tekniği ile analiz edilmiştir. Lisansüstü tezler; tezlerin türü, yıllara göre dağılımı, yapıldıkları üniversiteler, tez yazarlarının cinsiyet dağılımı, tez yazarlarının lisans mezuniyet dağılımı, danışman dağılımı, danışman ünvanı dağılımı, jüri dağılımı, izin durumu dağılımı, ana bilim dalı dağılımı, bilim dalı dağılımı, bölüm sayısı dağılımı, sayfa sayısı ortalamaları, en az ve en çok
\end{abstract}

\footnotetext{
* Çalışmaya katkılarından dolayı Sakarya Üniversitesi Maliye Bölümü öğretim üyesi Doç. Dr. Fatih Yardımcıoğlu'na teşekkür ederim.

1 Yard. Doç. Dr., Sakarya Üniversitesi IiBF Maliye Bölümü, fbesel@sakarya.edu.tr
} 
Anahtar Kelimeler: Lisansüstü Tezler,

Maliye, Belge

İncelemesi Yöntemi sayfa sayısı, sayfa aralığı dağııımı, anahtar kelime dağılımı, başlık ve özetlerde en sık kullanılan kelimeler, içerik ve yöntemlerine dair dağılım şeklinde tez türlerine göre karşılaştırılarak analiz edilmiştir. Bu araştırmanın, maliye alanında ileride yapılacak olan lisansüstü tezlerin çalışma konularının, içerik ve şekli unsurlarının belirlenmesinde araştırmacılara yol göstermesi hedeflenmektedir.

\section{Giriş}

Lisansüstü eğitim, lisans derecesini tamamlamış öğrencinin ilgi gösterdiği bilim dalında yüksek lisans veya doktora öğrenimi yaparak öğrenciye uzmanlaşma imkânı veren, üst düzey eğitim programıdır. Lisansüstü çalışmaların gerçekleştirilmesinde, ülkenin ihtiyaçlarına uygun programların yapılması, geliştirilmesi ve bu programları yürütecek öğretim elemanı kadrolarının yetiştirilmesi önem taşımaktadır. Bu bağlamda lisansüstü eğitimin bilimsel bilgi üretimi açısından üniversitelerin en önemli görevleri arasında yer aldığı söylenebilir.

Bozdoğan ve Bozdoğan (2011)'a göre maliyenin konusu, devletin ve diğer kamu kuruluşlarının ürettiği mal ve hizmetler, bu mal ve hizmetlerin üretilmesi aşamasında yapılan harcamalar ve bu harcamaların finansmanı için başvurulan gelir kaynaklarının incelenmesidir. Maliye Teorisi, Mali Hukuk, Mali İktisat ve Bütçe ve Mali Planlama olmak üzere dört ana bilim dalına ayrılan maliye bölümünün Türk eğitim yapısı içinde 1860'lı yıllardan itibaren yer aldığı görülmektedir (Bozdoğan \& Bozdoğan, 2011: 34). Günümüzde Türkiye'deki üniversitelerin 66 tanesinde maliye bölümünün olduğu görülmektedir².

Mali olayları inceleyen, mali olayların neden ve sonuçlarını araştıran Maliye bilimi önceleri ekonominin bir alt dalı olarak ortaya çıkmış olsa da dünya ekonomisinde yaşanan gelişmeler ile her geçen gün önem kazanmaktadır (Bozdoğan \& Bozdoğan, 2011: 35). Bu bağlamda maliye alanında yapılan teorik ve uygulamaya dayalı çalışmaların da hızla arttığı görülmektedir. Maliye biliminin artan bu önemi maliye alanında hazırlanan lisansüstü tezlerin nitelik ve nicelik açısından incelenmesini gerektirmektedir.

Lisansüstü tezlere yönelik farklı alanlarda farklı araştırmalar yapılmıştır. Özellikle eğitim bilimleri alanında yoğunlaşmış bu araştırmaların bibliyometrik analizler, tezlerin içerik analizi ve konu dağılımları, en sık atıf yapılan kaynaklar, kullanılan araştırma yöntemleri ve veri toplama teknikleri analizi şeklinde olduğu görülmektedir. Bir alanla ilgili yapılmış lisansüstü tezlerin analiz edilmesi o konunun derinliği ve yaygınlığı hakkında bilgiler verebilir, incelenen alanın genel görünümünü ortaya çıkarabilir (Karadağ, 2009: 76).

Farklı disiplinlerde lisansüstü tezleri inceleyen çok sayıda çalışma bulunmaktadır (Herubel 1991; Walcott 1991, 1994; Sylvia \& Lesher 1995; Zipp 1996; Buttlar 1999; Edwards 1999; Kuyper-Rushing 1999; Wehmeyer \& Wehmeyer 1999; Waugh \& Ruppel 2004; Şimşek vd. 2009; Uçak \& Al 2009; Tatlı \& Adıgüzel 2012; Şahin vd. 2013; Coşkun vd. 2014; Bayın 2015; Yorulmaz 2016). Ancak 2010 yılında Bozdoğan tarafından yapılan

\footnotetext{
${ }^{2}$ https://istatistik.yok.gov.tr/ Erişim Tarihi: 27.02.2017
} 
yüksek lisans tezi çalışması Türkiye'de Maliye alanında lisansüstü tezlerin analizinin yapıldığı tek çalışmadır. Ayrıca Bozdoğan ve Bozdoğan (2011) Türkiye'de maliye alanında akademik çalışmaların nicel görünümünü inceledikleri çalışmalarında ise maliye bölümü öğretim üyelerinin yayın performansı ve yayınlara ait analizler ile Türkiye'de maliye alanının fotoğrafını çekmişlerdir.

Türkiye'de lisansüstü maliye tezlerinin çeşitli parametrelere göre incelendiği Bozdoğan (2010)'ın çalışmasından sonra yapılmış bir çalışmanın bulunmaması, söz konusu çalışmanın güncellenerek daha kapsamlı analiz edilmesi amacıla araştırmanın Türkiye'de son on beş yılda (2003-2017) ${ }^{3}$ maliye alanında yapılan lisansüstü tezleri kapsamasına karar verilmiştir.

\section{Gereç ve Yöntem}

Bu çalışmada, belge (doküman) incelemesi veri toplama yöntemi kullanılmıştır. Derinlemesine görüşme ve gözlem yapmanın olanaklı olmadığı durumlarda başvurulan belge incelemesi hedeflenen olay ya da olgular hakkında yazılı bilgi içeren kaynakların ayrıntılı biçimde analiz edilmesidir (Güçlü Nergiz, 2014: 214). Doküman incelemesi tekniği ile yapılan bu çalışma yayınların farklı yöntemlerle analiz edilmesine ve bilimsel amaçlı çalışmaların değerlendirilmesine olanak sağlayan bibliyometrik araştırmalar şeklinde de adlandırılmaktadır (Coşkun vd., 2014: 381). Bibliyometrik yöntemler bilimsel çalışmaların sonuçlarının ve etkinliğinin ölçülmesini sağlamaktadır.

Bu çalışmanın amacı, maliye alanında Türkiye'de yapılmış olan lisansüstü tezlerin incelenmesidir. Bu amaçla, belirli bir alanda yapılmış tüm çalışmaları derleyerek, genel bir sonuca ulaşmayı hedefleyen içerik değerlendirmesi yöntemine başvurulmuş ve veriler, doküman incelemesi yoluyla toplanmıştır. Dolayısıyla, bu çalışmanın nitel bir araştırma tasarımı gösterdiği söylenebilir.

Çalışma kapsamda; tezlerin türü, yıllara göre dağılımı, yapıldıkları üniversiteler, tez yazarlarının cinsiyet dağılımı, tez yazarlarının lisans mezuniyet dağılımı, danışman dağılımı, danışman ünvanı dağılımı, jüri dağılımı, izin durumu dağılımı, ana bilim dalı dağılımı, bilim dalı dağılımı, bölüm sayısı dağılımı, sayfa sayısı ortalamaları, en az ve en çok sayfa sayısı, sayfa aralı̆̆ı dağılımı, anahtar kelime dağılımı, başlık ve özetlerde en sık kullanılan kelimeler, içerik ve yöntemlerine dair dağılım gibi özelliklerini özetlemek amaçlanmıştır.

Yüksek Öğretim Kurumu (YÖK) Ulusal Tez Merkezi veri tabanından 2003-2017 döneminde "Maliye", "Mali Hukuk" ve "Maliye ve Ekonomi" ana bilim dallarında yapılan lisansüstü tezler indirilerek analiz edilmiştir. Tarama sonucunda 1714 adet teze ulaşılmış ve araştırma kapsamında incelenmiştir.

Araştırma kapsamında, bazı tezlerin tam metnine ulaşılamadığından, tezlerin Ulusal Tez Merkezi'nde yer alan bilgileri incelenmiştir. Ulaşılamayan bilgiler nedeniyle

\footnotetext{
3 Analiz dönemi olarak 2003-2017 belirlenmiştir ancak YÖK Ulusal Tez Merkezi'nden tezlerin elde edildiği dönemde 2017 yılına ait yayınlanmış tez bulunmadığından bulgular 2003-2016 yılını kapsamaktadır. Erişim Tarihi: 15.01.2017
} 
bazı veriler boş bırakılmış ve analiz her alt başık için ulaşılabilen veriler bağlamında yapılmıştır.

\section{Bulgular}

\subsection{Lisansüstü Tezlerin Türü ve Yıllara Göre Dağılımı}

Çalışmada analiz edilen 1714 lisansüstü tezin \%19.5'i doktora, \%80.5'i ise yüksek lisans tezidir.

\section{Grafik 1. Lisansüstü Tezlerin Türü}

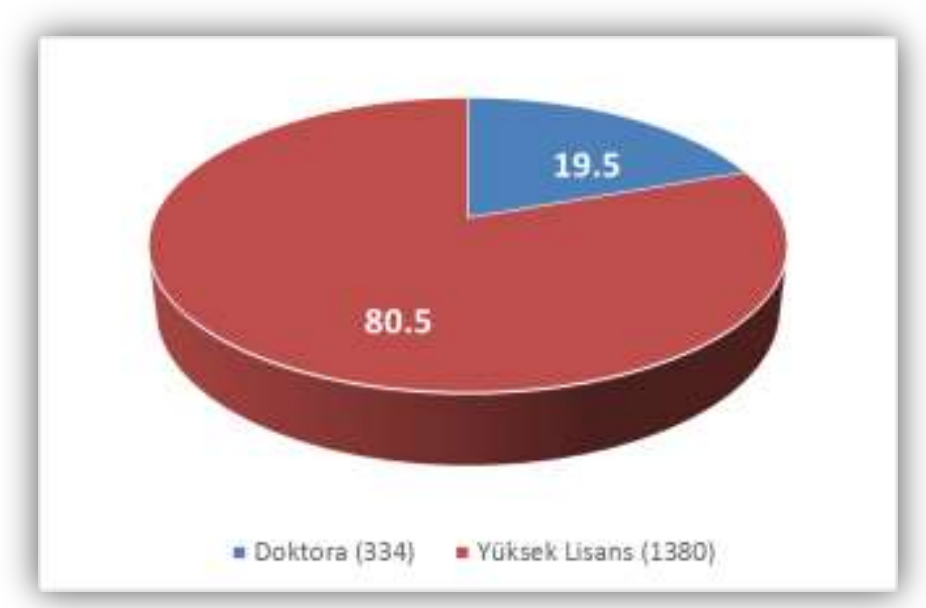

Kaynak: Lisansüstü tezler analiz edilerek yazar tarafından hazırlanmıştır.

2003-2017 yılları arasında yüksek lisans tezleri en çok sırasıyla 2010, 2006 ve 2011 yıllarında yazılmıştır. Yüksek lisans tezlerinin en az yazıldığı yıllar ise sırasıyla 2003, 2016 ve 2004 yıllarıdır.

\section{Grafik 2. Yüksek Lisans Tezleri Yıllara Göre Dağılım (\%)}

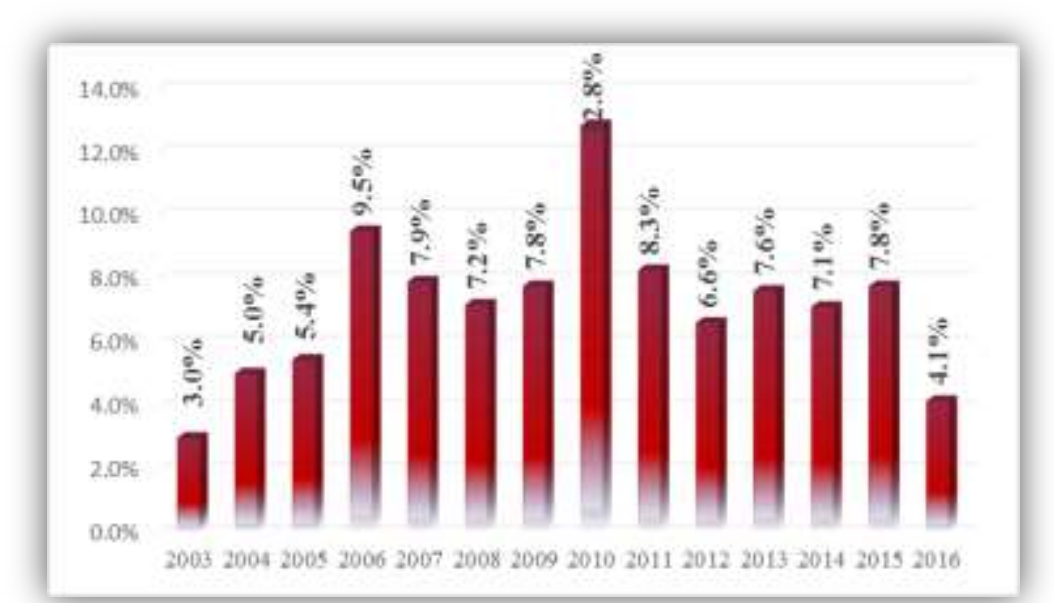

Kaynak: Lisansüstü tezler analiz edilerek yazar tarafından hazırlanmıştır. 
Ele alınan dönemde doktora tezleri en çok sırasıyla 2013, 2006, 2012 ve 2010 yıllarında yazılmıştır. Son on beş yılda doktora tezlerinin en az yazıldığı yıllar ise sırasıyla 2005, 2016, 2003 ve 2015 şeklindedir. Özellikle 2013 yılı sonrasında doktora tezlerinde yaşanan düşüş dikkat çekmektedir.

Grafik 3. Doktora Tezleri Yıllara Göre Dağılım (\%)

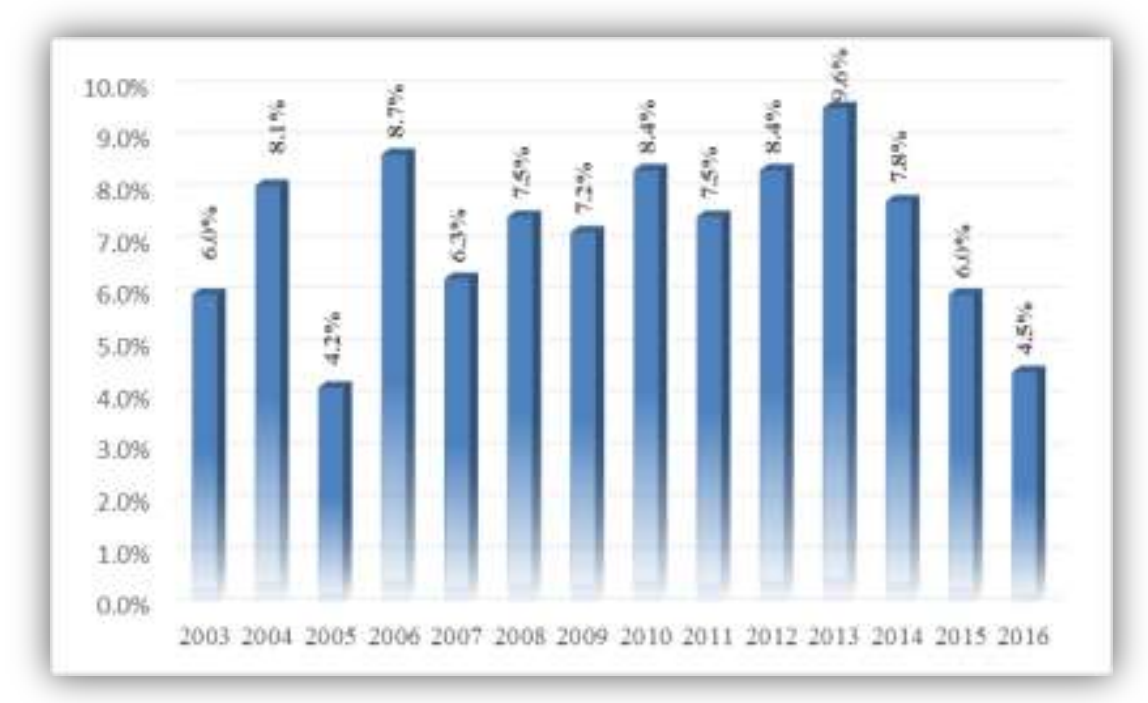

Kaynak: Lisansüstü tezler analiz edilerek yazar tarafından hazırlanmıştır.

Son on beş yılda Maliye alanında yazılan 1714 lisansüstü tezin tamamının yıllara göre dağılımı aşağıdaki grafikte sunulmuştur.

\section{Grafik 4. Lisansüstü Tezlerin Yıllara Göre Dağılımı (\%)}

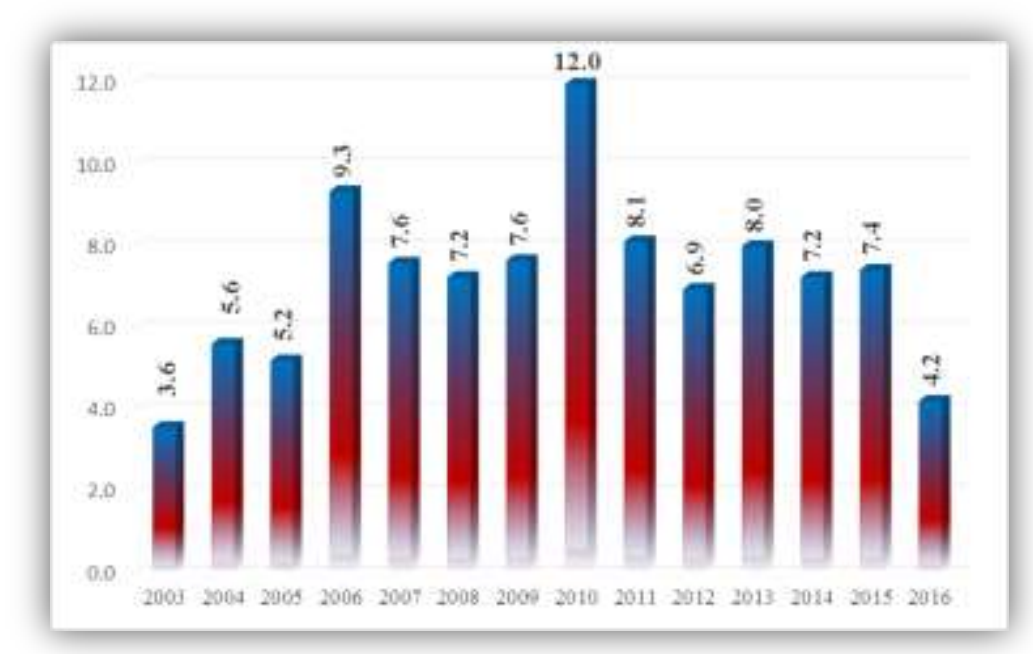

Kaynak: Lisansüstü tezler analiz edilerek yazar tarafından hazırlanmıştır.

Grafikten de görüldüğü üzere son on beş yılda Maliye alanında yazılan lisansüstü tezlerin en çok olduğu yıllar sırasıyla 2010, 2006 ve 2011 yıllarıdır. 2010 ve 2011 yıllarında lisansüstü tezlerin bitirilme oranının çok olma nedeni 15.03.2005 tarihli 
5316 sayılı "Yükseköğretim Kanununa Geçici Maddeler Eklenmesine Dair Kanun" ile lisansüstü öğrencileri de içeren af uygulaması olabilir. En az lisansüstü tez yazılan yıllar ise 2003, 2016 ve 2005 yıllarıdır.

\subsection{Lisansüstü Tezlerin Üniversitelere Göre Dağılımı}

Son on beş yılda Maliye alanında yapılan yüksek lisans tezlerinin \%12.5'i Marmara Üniversitesi, \%11.8'i İstanbul Üniversitesi ve \%11.2'si Dokuz Eylül Üniversitesi'nde tamamlanmıştır. Yüksek lisans çalışmalarında söz konusu üç üniversitenin diğer üniversitelere nazaran ön planda olduğu görülmektedir. Yüksek lisans çalışmalarının tamamlandığı en çok 15 üniversite ise aşağıdaki grafikte sunulmuştur.

\section{Grafik 5. Yüksek Lisans Tezleri Üniversitelere Göre Dağılımı (\%)}

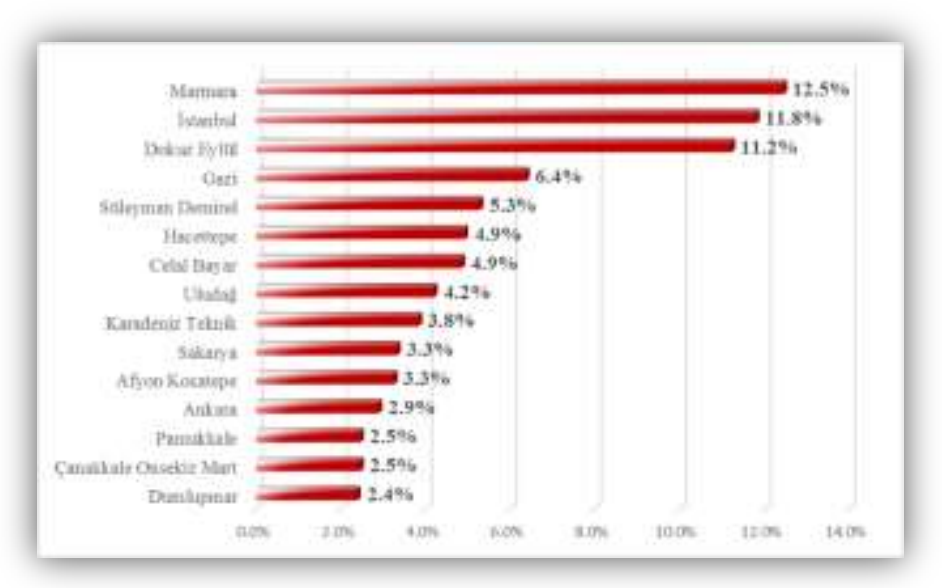

Kaynak: Lisansüstü tezler analiz edilerek yazar tarafından hazırlanmıştır.

Yüksek lisans tezlerinde olduğu gibi doktora tezlerinin de en çok yapıldığı üç üniversite aynıdır. Marmara üniversitesi hem yüksek lisans hem de doktora tezi çalışmalarının en çok olduğu üniversitedir.

\section{Grafik 6. Doktora Tezleri Üniversitelere Göre Dağılım}

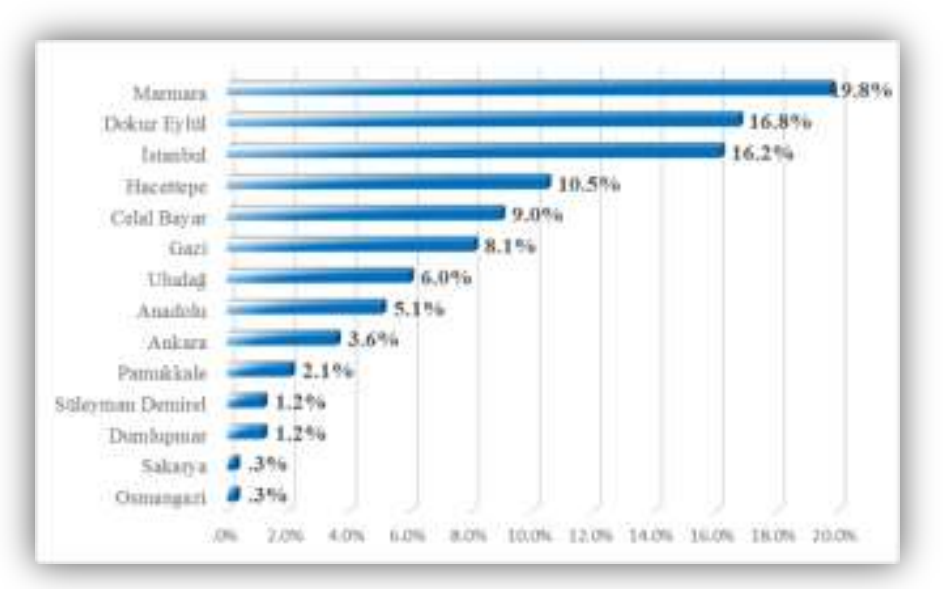

Kaynak: Lisansüstü tezler analiz edilerek yazar tarafından hazırlanmıştır. 
Yüksek lisans tezlerinden farklı olarak doktora tezlerinde ikinciliği İstanbul Üniversitesi'nden Dokuz Eylül Üniversitesi'nin aldığı görülmektedir. Ayrıca yüksek lisans tezlerinde 4. sırada yer alan Gazi Üniversitesi doktora tezlerinde 6. sırada yer almaktadır. Doktora tezlerinde 4. sırada ise Hacettepe Üniversitesi bulunmaktadır.

\section{Grafik 7. Lisansüstü Tezlerin Üniversitelere Göre Dağılımı}

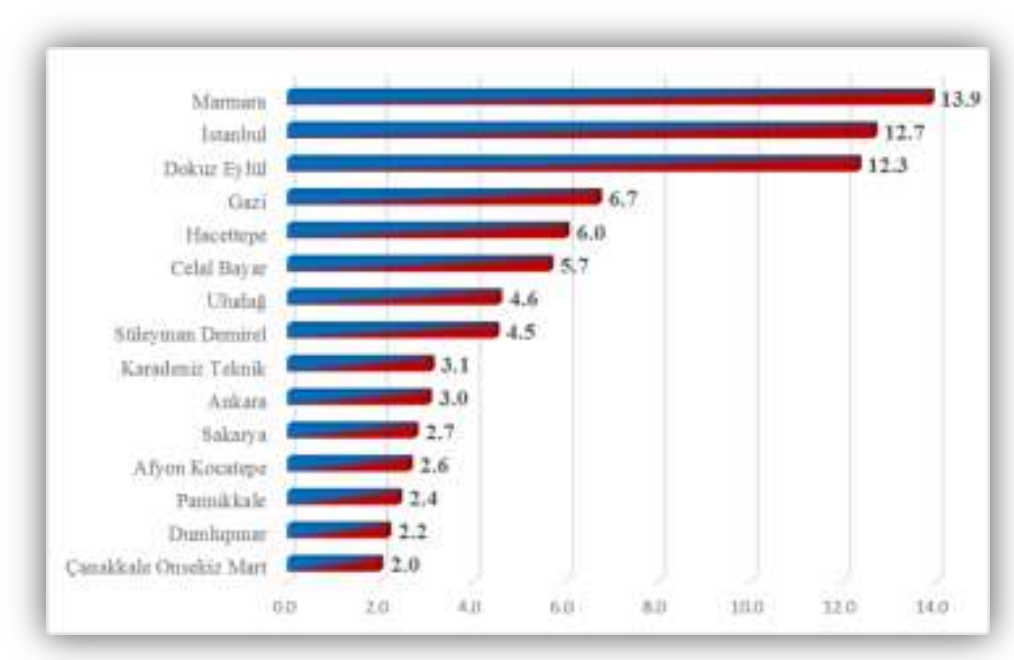

Kaynak: Lisansüstü tezler analiz edilerek yazar tarafından hazırlanmıştır.

Son on beş yılda Maliye alanında en çok lisansüstü çalışmanın tamamlandığı üniversiteler sırasıyla Marmara Üniversitesi, İstanbul Üniversitesi, Dokuz Eylül Üniversitesi, Gazi Üniversitesi ve Hacettepe Üniversitesi şeklindedir.

\subsection{Lisansüstü Tezlerin Yazarlarının Cinsiyet Dağılımı}

Çalışmada analiz edilen 1714 lisansüstü tez çalışmasının yazarlarının cinsiyetleri aşağıdaki grafikte gösterimiştir.

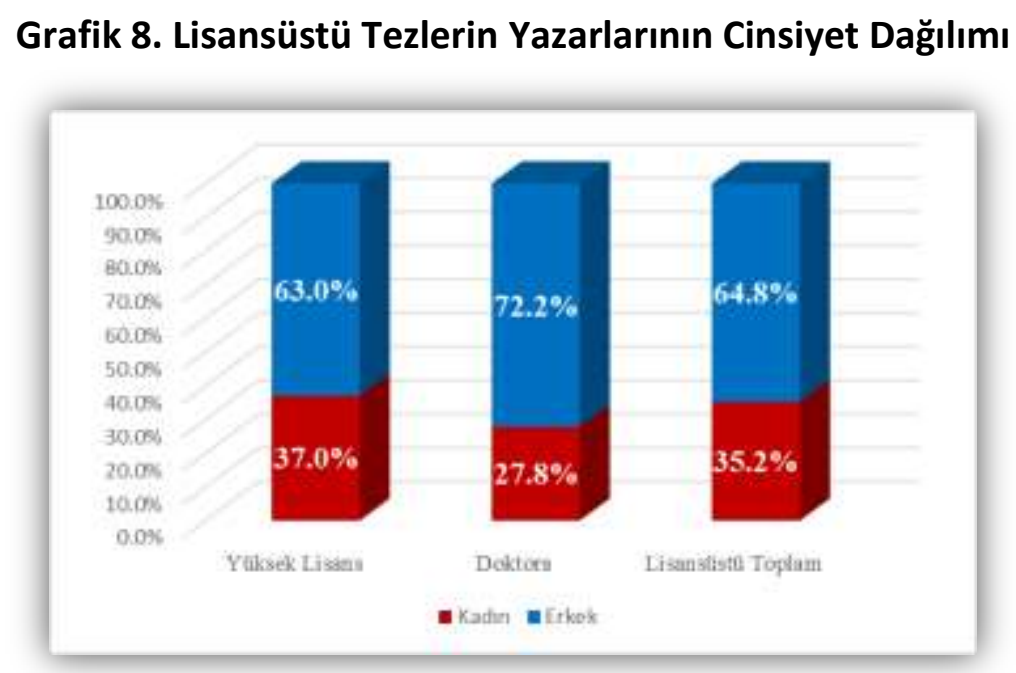

Kaynak: Lisansüstü tezler analiz edilerek yazar tarafından hazırlanmıştır. 
Yüksek lisans tez yazarlarının \%37'si kadın, \%63'ü erkek ; doktora tez yazarlarının \%27.8'i kadın, \%72.2'si erkek ; lisansüstü tez yazarlarının ise \%35.2'si kadın, \%64.8'i erkektir. Buna göre kadınların doktora çalışmalarına nazaran yüksek lisans çalışmalarında daha çok, erkeklerin ise doktora çalışmalarında yüksek lisans çalışmalarına nazaran daha çok yer aldığı görülmektedir. Elde edilen sonuçlar bağlamında erkeklerin kadınlara nazaran lisansüstü eğitime daha çok ilgi gösterdiği belirtilebilir.

\subsection{Lisansüstü Tez Yazarlarının Lisans Mezuniyetleri Dağılımı}

Çalışmanın bu kısmında lisansüstü tezlerden elde edilen yazarların özgeçmiş bilgileri doğrultusunda Maliye alanında lisansüstü çalışma yapan yazarların lisans mezunu oldukları bölüm ve üniversiteleri analiz edilecektir.

Lisansüstü tezlerin yaklaşık \%75'inde yazarların özgeçmişlerinin yer almadığı görülmektedir.

\section{Grafik 9. Lisansüstü Tezlerde Yazarların Özgeçmişi Bulunma Dağılımı}

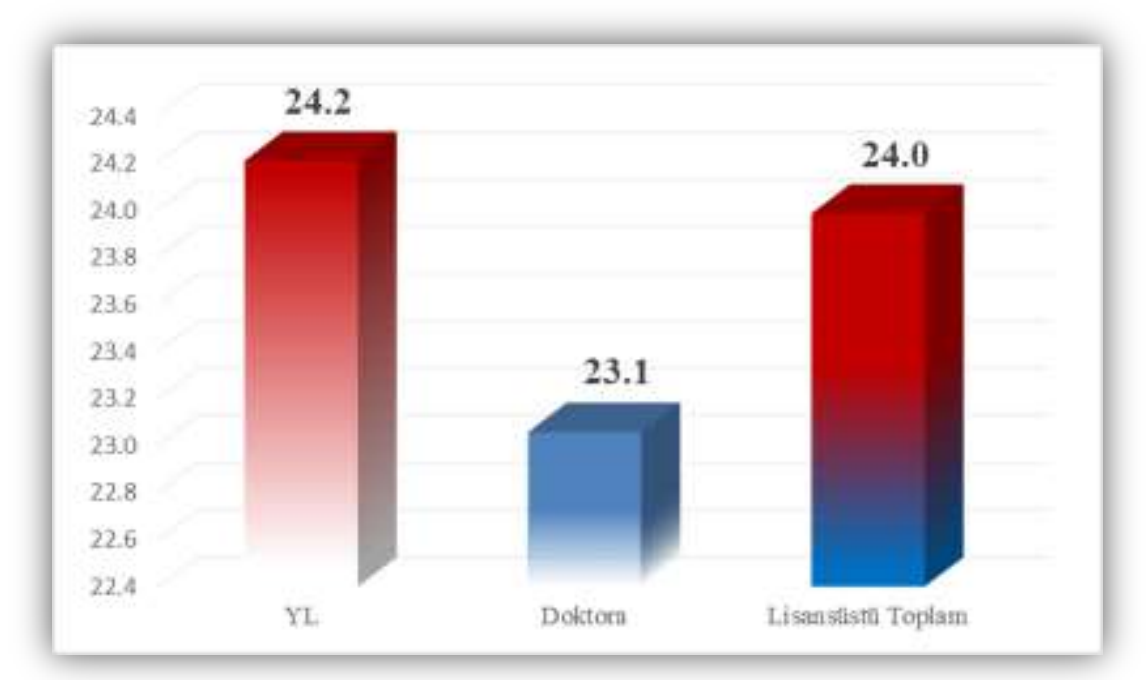

Kaynak: Lisansüstü tezler analiz edilerek yazar tarafından hazırlanmıştır.

Maliye alanında yüksek lisans yapanların ${ }^{4}$ en çok sırasıyla Uludağ Üniversitesi, Karadeniz Teknik Üniversitesi ve Süleyman Demirel Üniversitesi lisans mezunu oldukları görülmektedir.

\footnotetext{
${ }^{4}$ Yüksek lisans tezlerinin 334 tanesinde yazarların özgeçmişi yer almaktadır. Analiz bu çerçevede yapılmıştır.
} 


\section{Grafik 10. Yüksek Lisans Tezi Yazarlarının Lisans Mezunu Olduğu Üniversite}

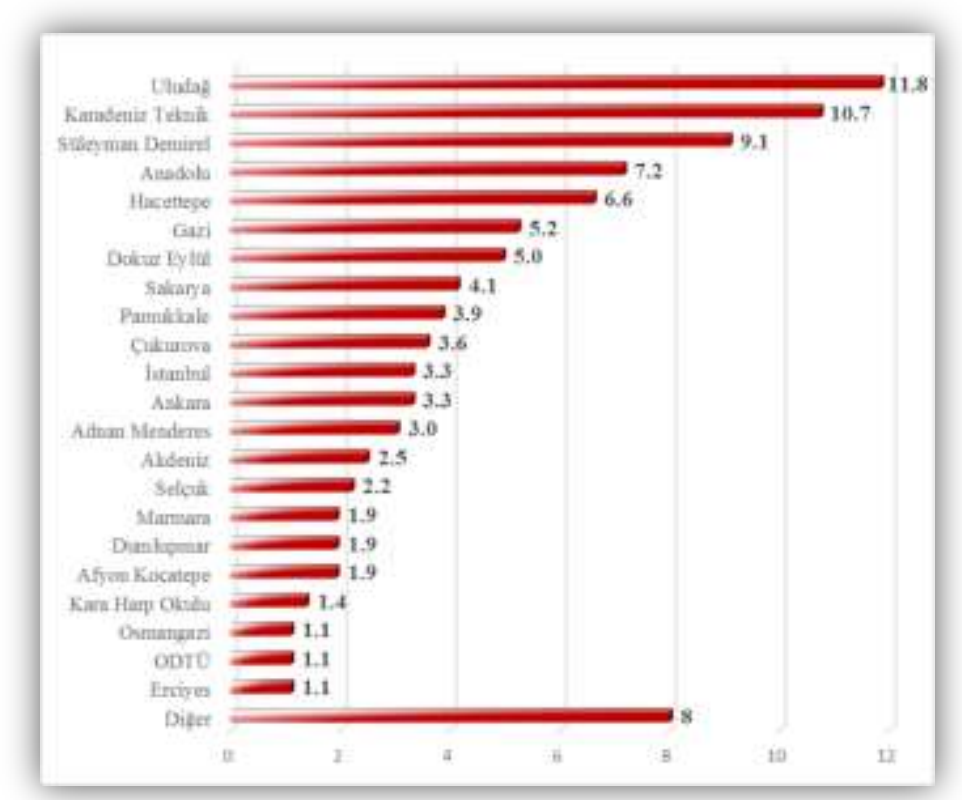

Kaynak: Lisansüstü tezler analiz edilerek yazar tarafından hazırlanmıştır.

Maliye alanında doktora yapanların ${ }^{5}$ ise en çok sırasıyla İstanbul Üniversitesi, Anadolu Üniversitesi ve Uludağ Üniversitesi lisans mezunu oldukları görülmektedir.

\section{Grafik 11. Doktora Tezi Yazarlarının Lisans Mezunu Olduğu Üniversite}

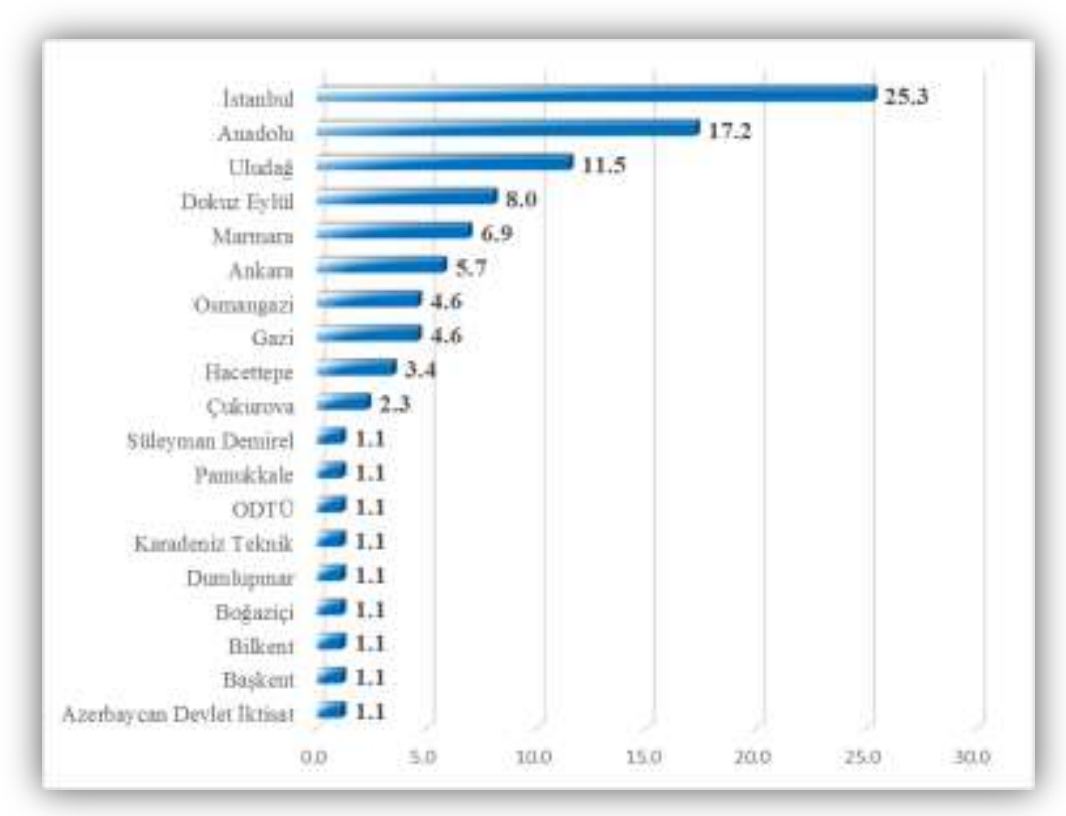

Kaynak: Lisansüstü tezler analiz edilerek yazar tarafından hazırlanmıştır.

\footnotetext{
${ }^{5}$ Doktora tezlerinin 77 tanesinde yazarların özgeçmişi yer almaktadır. Analiz bu çerçevede yapılmıştır.
} 
Maliye alanında lisansüstü çalışma yapanların tamamı ele alındığında ise yazarların en çok sırasıyla Uludağ Üniversitesi, Anadolu Üniversitesi ve Karadeniz Teknik Üniversitesi'nde lisans eğitimlerini tamamladıkları görülmektedir.

\section{Grafik 12. Lisansüstü Tez Yazarlarının Lisans Mezunu Olduğu Üniversite}

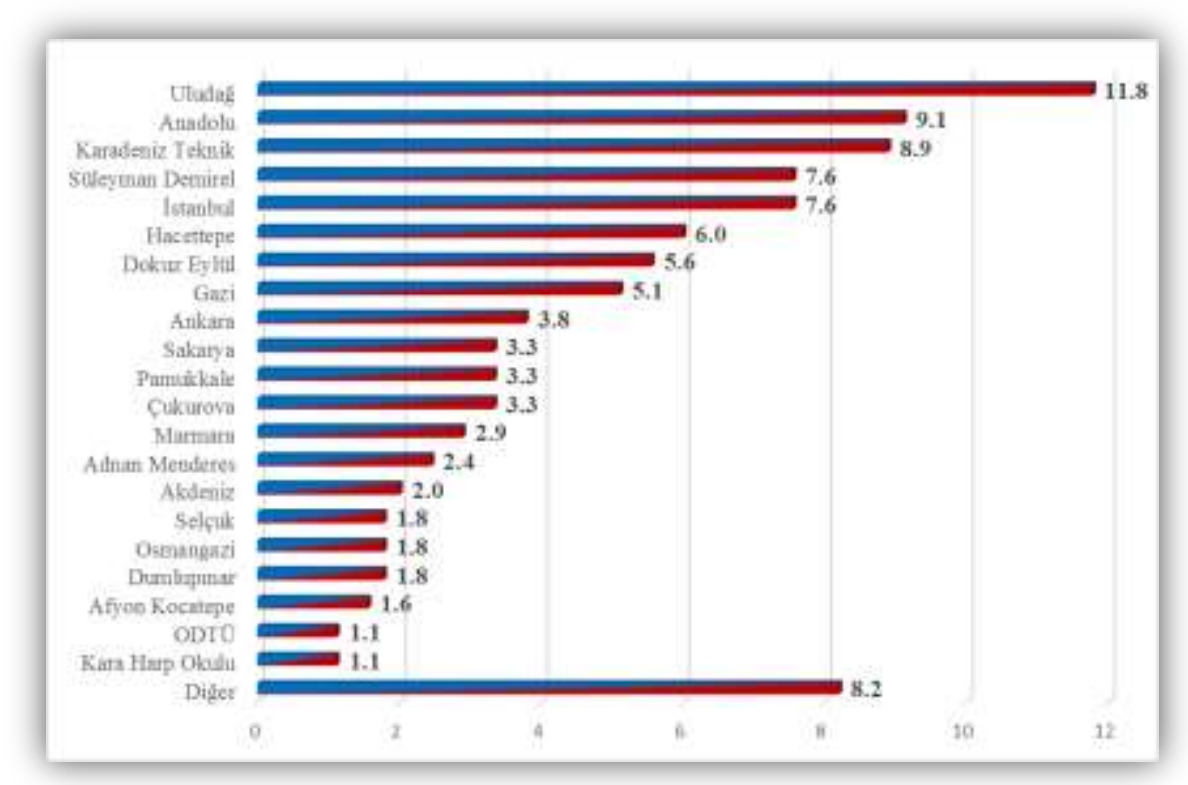

Kaynak: Lisansüstü tezler analiz edilerek yazar tarafından hazırlanmıştır.

Maliye alanında yüksek lisans derecesi alanların mezun oldukları lisans bölümleri aşağıdaki grafikte gösterilmiştir.

\section{Grafik 13. Yüksek Lisans Tezi Yazarlarının Mezun Olduğu Bölümler}

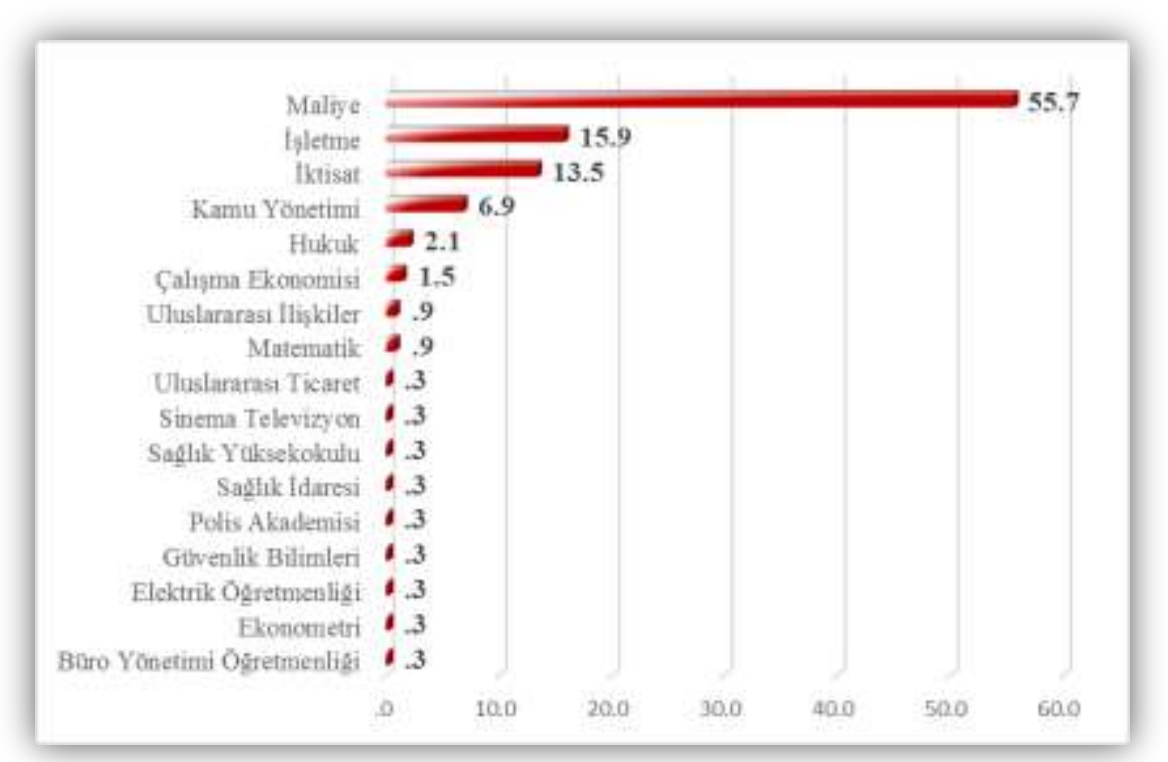

Kaynak: Lisansüstü tezler analiz edilerek yazar tarafından hazırlanmıştır. 
Maliye alanında yüksek lisans yapanların \%55.7'sinin lisans mezuniyetinin de Maliye bölümünden olduğu görülmektedir. Bununla birlikte Maliye alanında yüksek lisans yapanların ağırlıklı olarak sırasıyla İşletme, İktisat ve Kamu Yönetimi bölümleri mezunları oldukları belirtilebilir.

\section{Grafik 14. Doktora Tezi Yazarlarının Mezun Olduğu Bölümler}

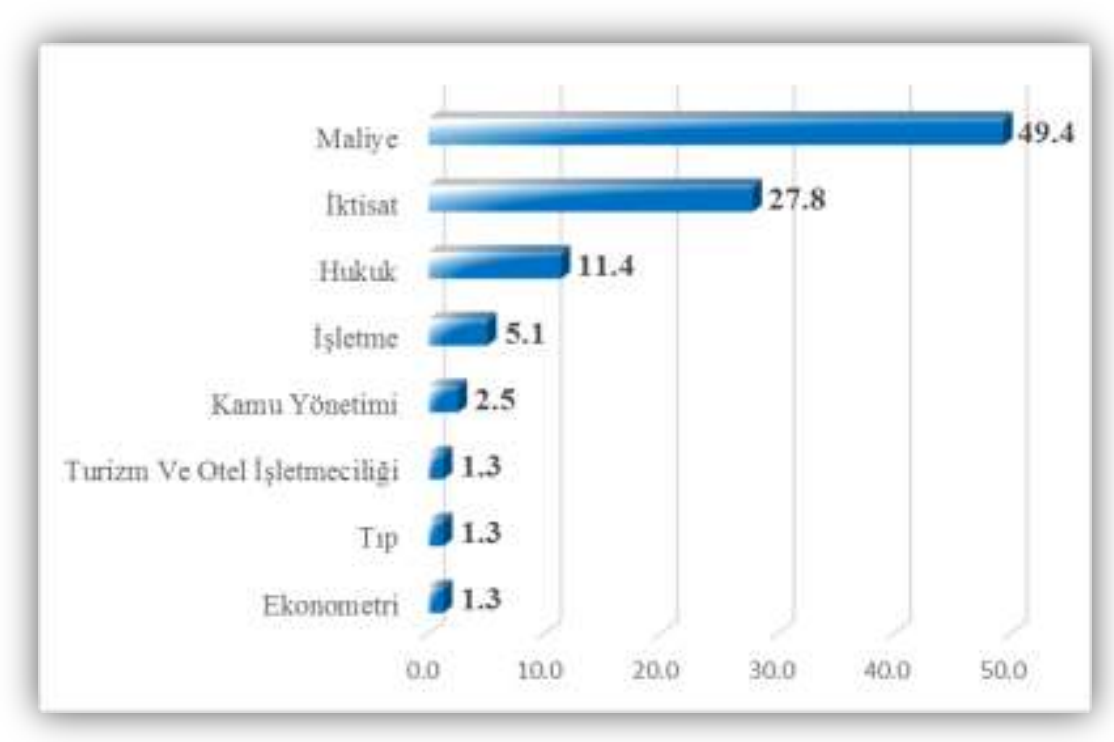

Kaynak: Lisansüstü tezler analiz edilerek yazar tarafından hazırlanmıştır.

Maliye alanında doktora yapanların \%49.4'ü Maliye, \%27.8'i iktisat, \%11.4'ü Hukuk, \%5.1'i İşletme, \%2.5'i Kamu Yönetimi, \%1.3'ü Turizm ve Otel İşletmeciliği, \%1.3'ü Tıp Fakültesi, \%1.3'ü Ekonometri mezunudur.

\section{Grafik 15. Lisansüstü Tez Yazarlarının Mezun Olduğu Bölümler}

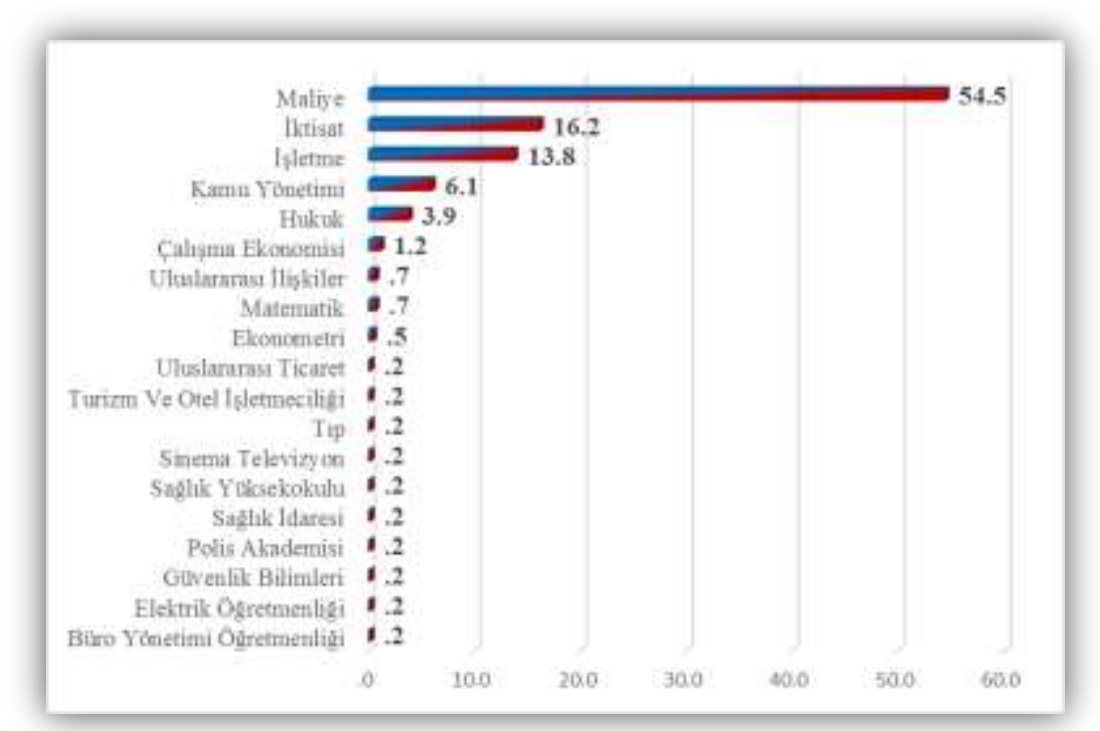

Kaynak: Lisansüstü tezler analiz edilerek yazar tarafından hazırlanmıştır. 
Maliye alanında lisanüstü tez yazarlarının tamamı dikkate alındığında lisans mezunu olunan bölümler sırasıyla \%54.5'i Maliye, \%16.2'si i̇ktisat, \%13.8'i İşletme şeklindedir.

\subsection{Lisansüstü Tezlerin Danışman, Danışman Ünvanı ve Jüri Dağılımı}

Maliye alanında son on beş yılda tamamlanan yüksek lisans tezlerinde 290 farklı öğretim üyesi danışmanlık yapmıştır. En çok danışmanlık yapan öğretim üyeleri sırasıyla Prof. Dr. Salim Ateş Oktar, Prof. Dr. Ibrahim Atilla Acar ve Prof. Dr. Şükrü Kızılot'tur.

\section{Grafik 16. Yüksek Lisans Tezlerinin Danışmanlara Göre Dağılımı}

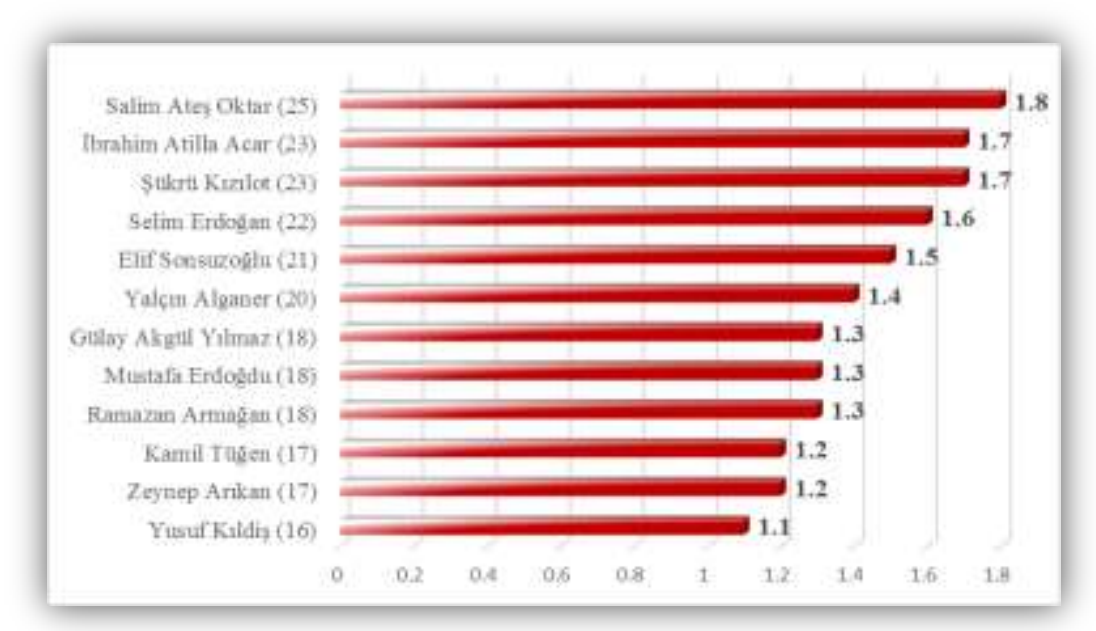

Kaynak: Lisansüstü tezler analiz edilerek yazar tarafından hazırlanmıştır.

Maliye alanında son on beş yılda tamamlanan doktora tezlerinde 104 farklı öğretim üyesi danışmanlık yapmış ve en çok danışmanlık yapan öğretim üyeleri sırasıyla Yrd. Doç. Dr. Ahmet Bumin Doğrusöz, Prof. Dr. Ahmet Kemal Çelebi, Prof. Dr. Fevzi Devrim, Prof. Dr. Mehmet Tosuner, Prof. Dr. Nurettin Bilici ve Prof. Dr. Ömer Faruk Batırel'dir.

\section{Grafik 17. Doktora Tezlerinin Danışmanlara Göre Dağılımı}




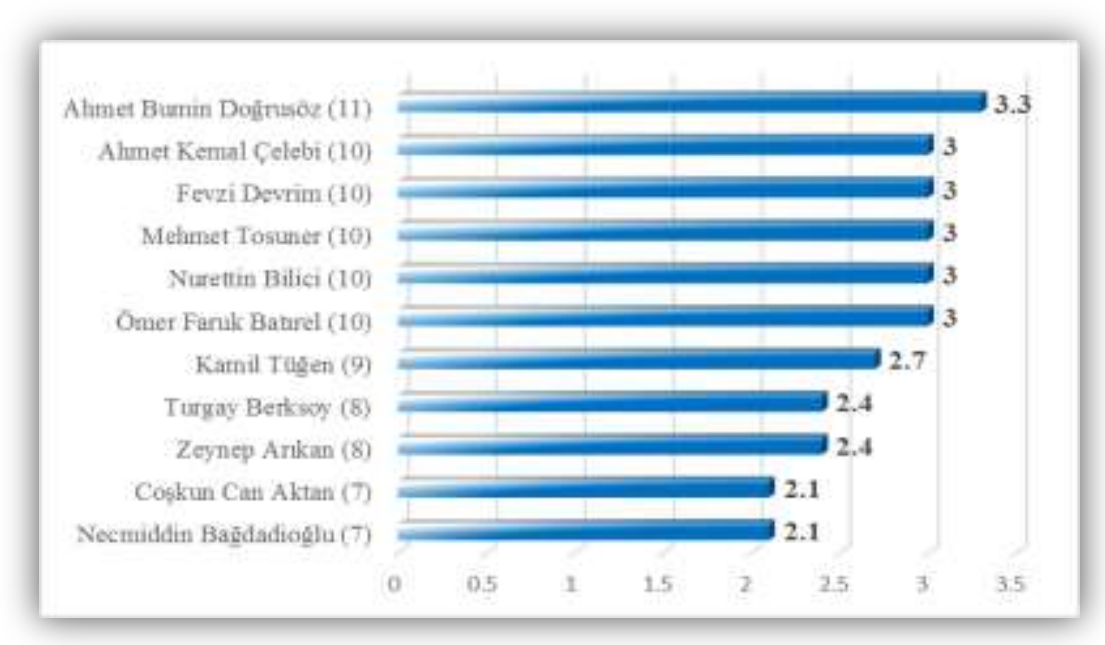

Kaynak: Lisansüstü tezler analiz edilerek yazar tarafından hazırlanmıştır.

Maliye alanında son on beş yılda tamamlanan lisanüstü tezlerin tamamı değerlendirildiğinde 300 farklı öğretim üyesinden en çok danışmanlık Prof. Dr. Salim Ateş Oktar, Prof. Dr. Şükrü Kızılot, Prof. Dr. Kamil Tüğen, Yrd. Doç. Dr. Ahmet Bumin Doğrusöz ve Prof. Dr. Zeynep Arıkan tarafından yapıldığı görülmektedir.

\section{Grafik 18. Lisansüstü Tezlerin Danışmanlara Göre Dağılımı}

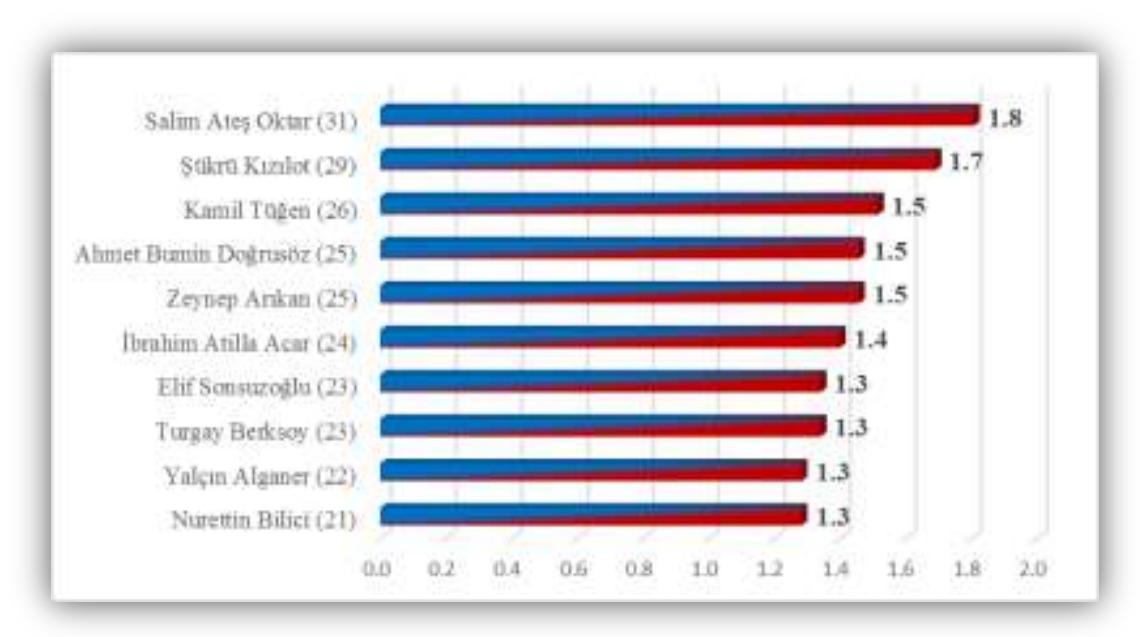

Kaynak: Lisansüstü tezler analiz edilerek yazar tarafından hazırlanmıştır.

Son on beş yılda Maliye alanında yapılan lisansüstü tezlere danışmanlık yapan öğretim üyelerinin ünvanlarına göre dağılımı aşağıdaki grafikte sunulmuştur.

\section{Grafik 19. Lisansüstü Tezlerin Danışman Ünvanlarına Göre Dağılımı}




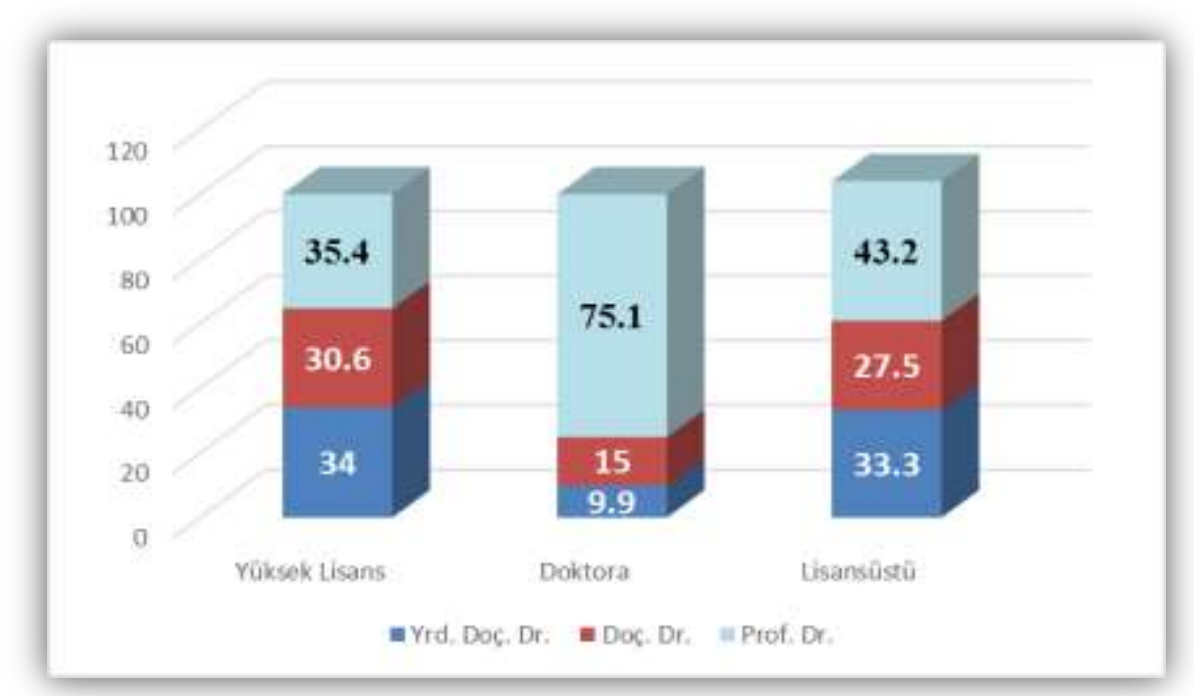

Kaynak: Lisansüstü tezler analiz edilerek yazar tarafından hazırlanmıştır.

2003-2017 döneminde yüksek lisans tezlerine danışmanlık yapan öğretim üyesi ünvanlarının dağılımı \%30.6'sı Doç. Dr., \%34'ü Yrd. Doç. Dr., \%35.4'ü Prof. Dr. şeklindedir. Ünvanların doktora tezlerindeki dağılımında ise Prof. Dr. ünvanı dikkate değer bir farkla ön plana çıkmaktadır. Buna göre doktora tezi danışmanlarının \%9.9'u Yrd. Doç. Dr., \%15'i Doç. Dr. ve \%75.1'i de Prof. Dr. ünvanına sahiptir. Lisansüstü tezlerin tamamı birlikte değerlendirildiğinde ise ünvanlar arasında daha dengeli bir dağılım olduğu görülmektedir. Lisansüstü tez danışmanlarının \%27.5’i Doç. Dr., \%33.3’ü Yrd. Doç. Dr. iken \%43.2'si Prof. Dr. 'dur.

Yüksek Lisans tezlerinin savunma jürilerinde en çok görev alan on beş öğretim üyesi aşağıdaki grafikte gösterilmiştir.

\section{Grafik 20. Yüksek Lisans Tezlerinde En Çok Jüride Yer Alan Öğretim Üyeleri}

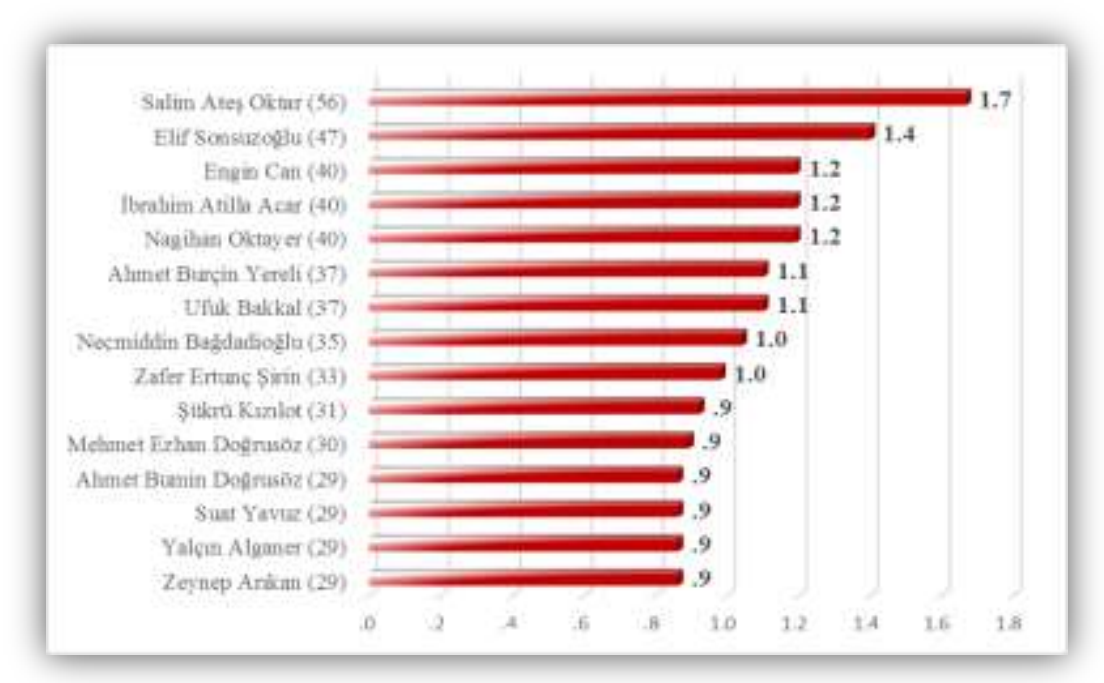

Kaynak: Lisansüstü tezler analiz edilerek yazar tarafından hazırlanmıştır. 
Yüksek Lisans tez savunmalarında en çok yer alan 5 öğretim üyesi sırasıyla; Prof. Dr. Salim Ateş Oktar, Prof. Dr. Elif Sonsuzoğlu, Prof. Dr. Nagihan Oktayer, Prof. Dr. Ibrahim Atilla Acar ve Yrd. Doç. Dr. Engin Can'dır. Doktora tez savunma jürilerinde en çok yer alan öğretim üyeleri listesinin yüksek lisans jürilerinden farklı olduğu görülmektedir.

\section{Grafik 21. Doktora Tezlerinde En Çok Jüride Yer Alan Öğretim Üyeleri}

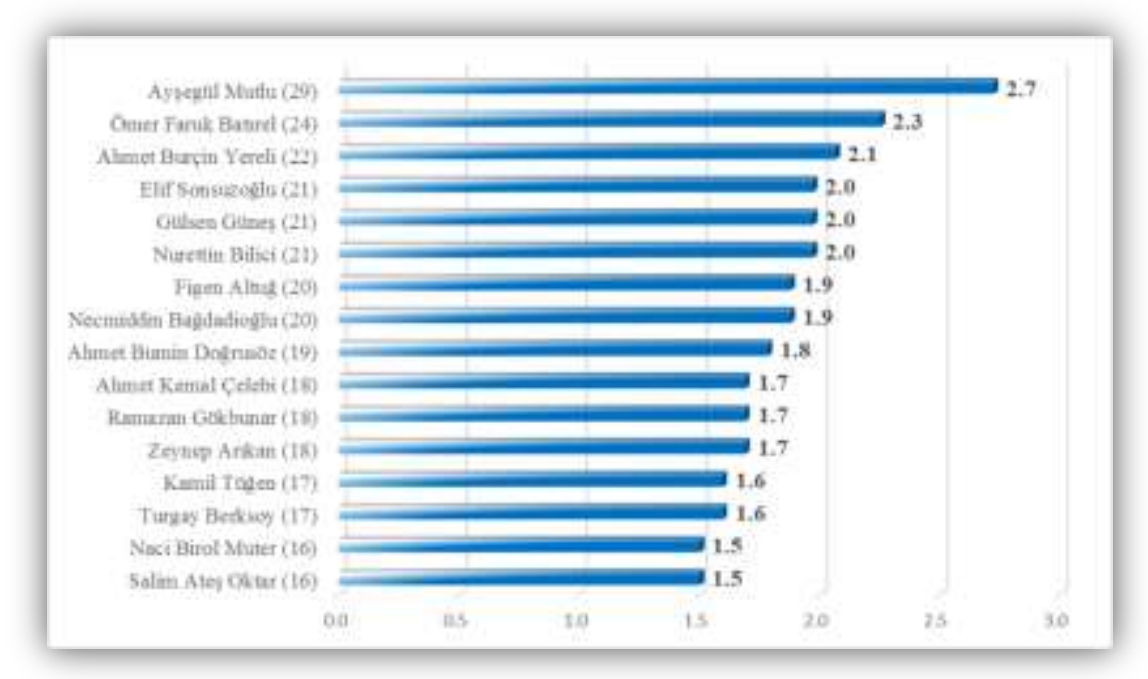

Kaynak: Lisansüstü tezler analiz edilerek yazar tarafından hazırlanmıştır.

Doktora savunmalarında jürilerde en çok Prof. Dr. Ayşegül Mutlu, Prof. Dr. Ömer Faruk Batırel, Prof. Dr. Ahmet Burçin Yereli, Prof. Dr. Nurettin Bilici, Prof. Dr. Gülsen Güneş ve Prof. Dr. Elif Sonsuzoğlu öğretim üyelerinin yer aldığı görülmektedir.

\section{Grafik 22. Lisansüstü Tezlerde En Çok Jüride Yer Alan Öğretim Üyeleri}

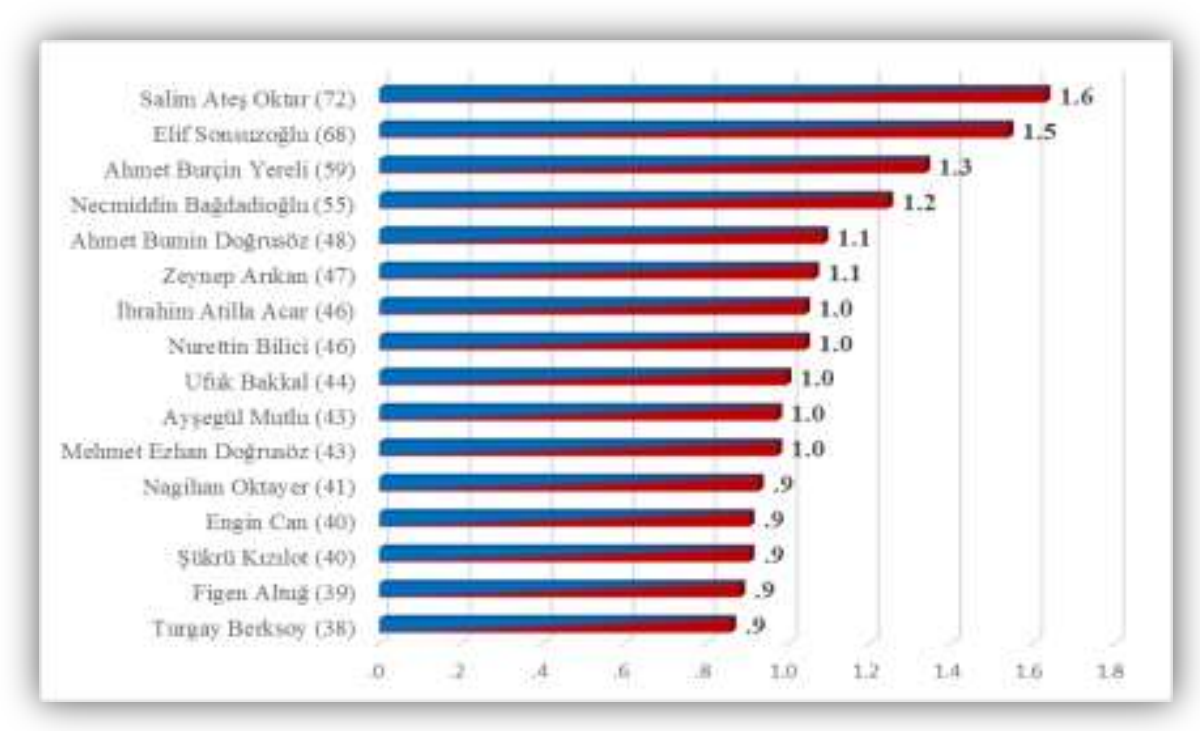

Kaynak: Lisansüstü tezler analiz edilerek yazar tarafından hazırlanmıştır.

Lisansüstü tez savunmalarında jürilerde en çok sırasıyla Prof. Dr. Salim Ateş Oktar (72), Prof. Dr. Elif Sonsuzoğlu (68), Prof. Dr. Ahmet Burçin Yereli (59), Prof. Dr. 
Necmiddin Bağdadioğlu (55), Yrd. Doç. Dr. Ahmet Bumin Doğrusöz (48) ve Prof. Dr. Zeynep Arıkan (47) öğretim üyelerinin yer aldığı görülmektedir.

\subsection{Lisansüstü Tezlerin İzin Durumu, Ana Bilim Dalı, Bilim Dalı Dağılımı}

Çalışmada analiz edilen 1714 lisansüstü tezin \%18'i izinsiz veya indirilemez durumdadır.

\section{Grafik 23. Lisansüstü Tezlerin İzin Durumu}

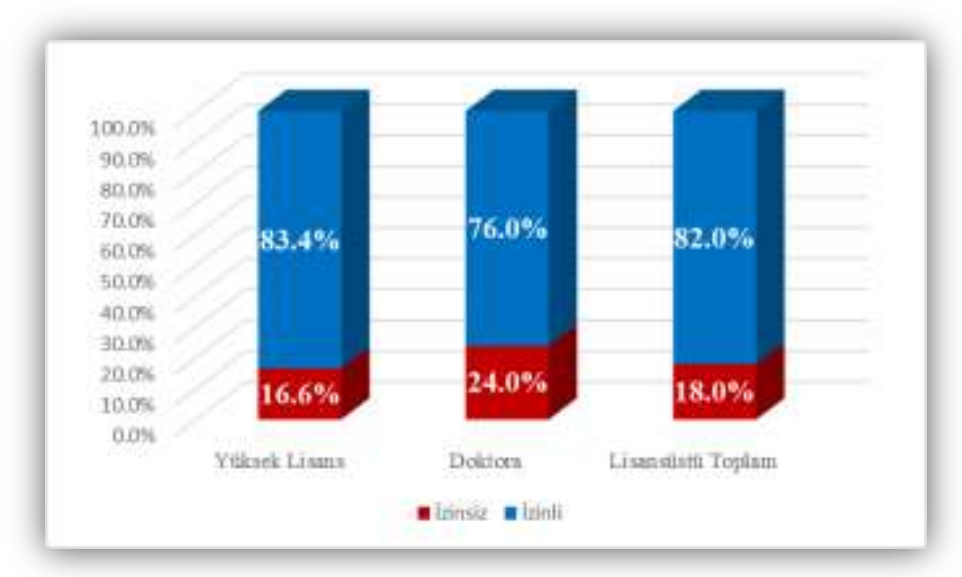

Kaynak: Lisansüstü tezler analiz edilerek yazar tarafından hazırlanmıştır.

Yüksek lisans tezlerinin \%16.6'sı izinsiz veya indirilemez durumda iken bu oran doktora tezleri için \%24 düzeyindedir. Dolayısıyla oran olarak doktora tezlerine ulaşabilme imkanının yüksek lisans tezlerine kıyasla daha düşük olduğu belirtilebilir. Doktora tezlerinin kitap olarak yayınlanması nedeniyle söz konusu farklılığın ortaya çıktığı söylenebilir.

Araştırmada incelenen 1714 lisansüstü tezin ana bilim dallarına göre dağılımı \%95.2'si Maliye ana bilim dalı, \%3.4'ü Mali Hukuk ana bilim dalı, \%1.5'i ise Maliye ve Ekonomi ana bilim dalı şeklindedir. Yüksek lisans tezleri özelinde incelendiğinde tezlerin \%94.6'sının Maliye ana bilim dalı, \%3.6'sının Mali Hukuk ana bilim dalı, \%1.8'inin ise Maliye ve Ekonomi ana bilim dalında çalışıldığı ifade edilebilir. Mali Hukuk ve Maliye ve Ekonomi ana bilim dallarına ilişkin oranların düşük olması üniversitelerin çoğunda bu ana bilim dallarına ilişkin lisansüstü eğitim programlarının bulunmamasından kaynaklanmaktadır.

\section{Grafik 24. Lisansüstü Tezlerin Ana Bilim Dalı Dağılımı}




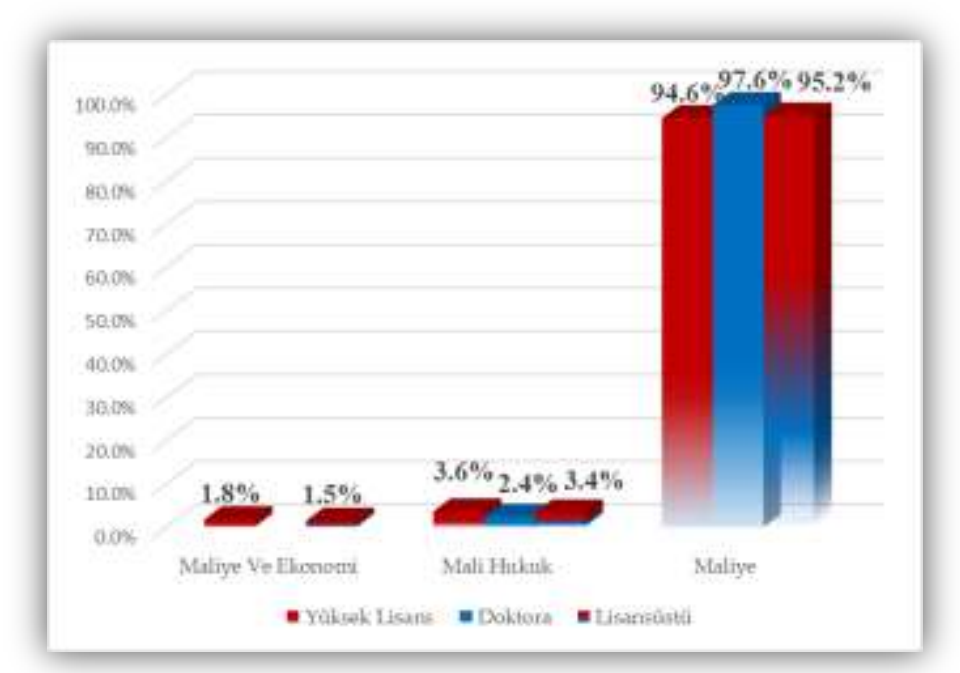

Kaynak: Lisansüstü tezler analiz edilerek yazar tarafından hazırlanmıştır.

Doktora tezlerinde ana bilim dallarına göre dağılım ise \%97.6 Maliye, \%2.4 Mali Hukuk şeklindedir. Maliye ve Ekonomi ana bilim dalında doktora programı bulunmamaktadır.

Çalışmada ayrıca bilim dalı veya programı şeklinde belirtilmiş olan lisansüstü tezler için bilim dalı ayrımı aşağıdaki grafikte gösterilmiştir. Buna göre lisansüstü tezlerin bilim dalı dağılımında ilk dört sırada yer alan \%39.2 Mali Hukuk, \%30.6 Maliye, \%15.6 Maliye Teorisi ve \%9.3 Mali İktisat ön plana çıkmaktadır.

\section{Grafik 25. Lisansüstü Tezlerin Bilim Dalı Dağılımı}

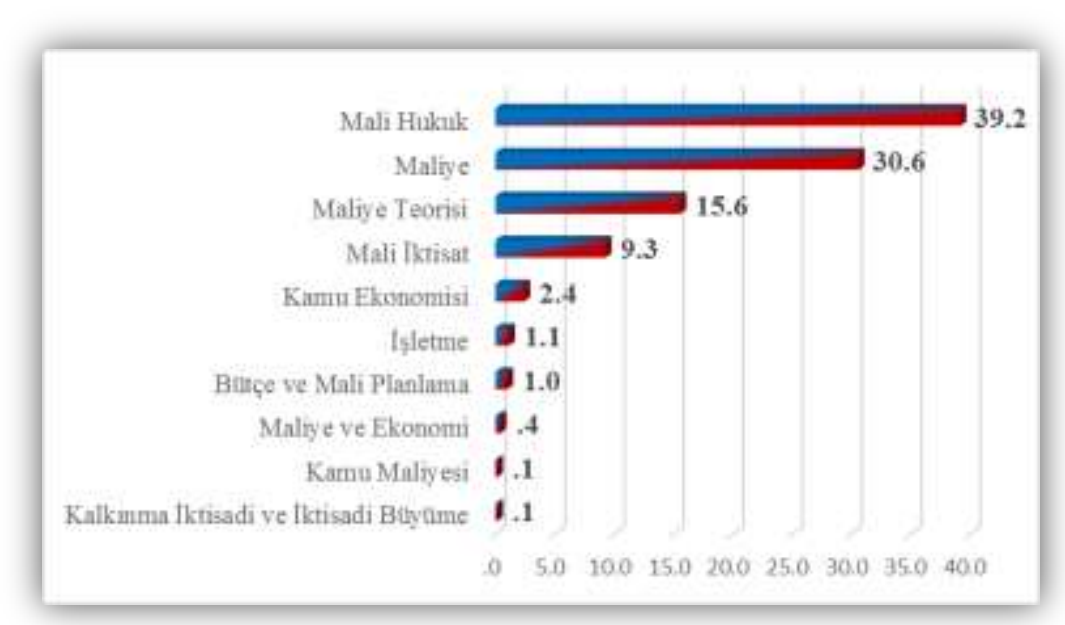

Kaynak: Lisansüstü tezler analiz edilerek yazar tarafından hazırlanmıştır. 
Yüksek lisans tezlerinin bilim dalı dağılımında da ilk dört sırada \%40.5 Mali Hukuk, \%31.4 Maliye, \%14.8 Maliye Teorisi ve \%8.4 Mali İktisat yer almaktadır.

\section{Grafik 26. Yüksek Lisans Tezleri Bilim Dalı Dağılımı}

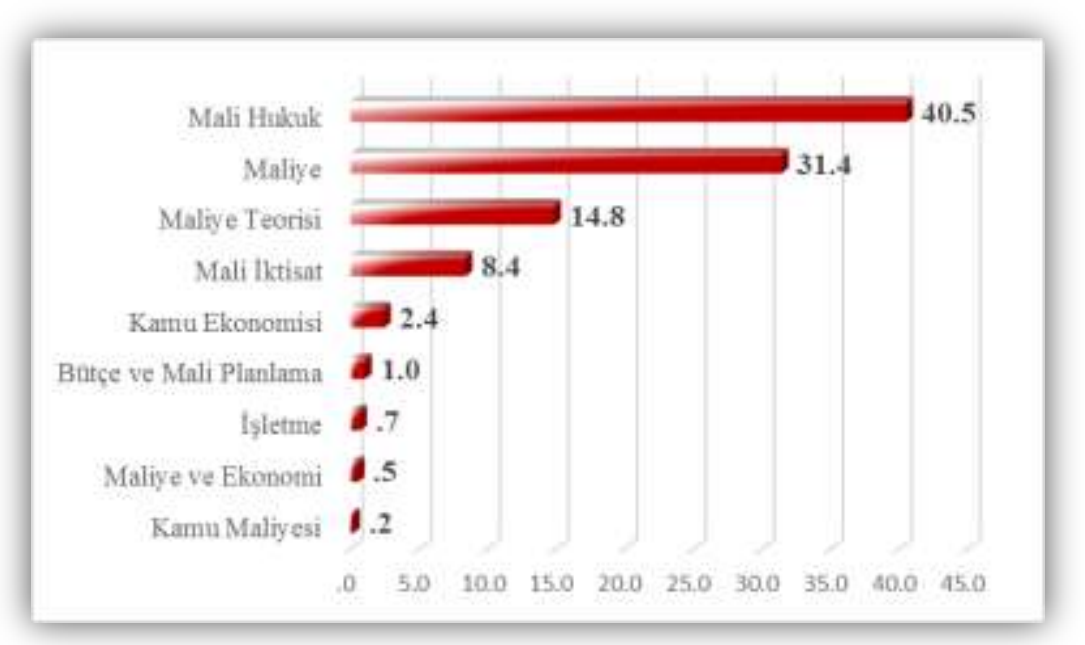

Kaynak: Lisansüstü tezler analiz edilerek yazar tarafından hazırlanmıştır.

Bilim dalı dağılımı doktora tezlerinde de lisansüstü tezlerin tamamına ve yüksek lisans tezlerine benzer şekilde \%33.3 Mali Hukuk, \%27 Maliye, \%19 Maliye Teorisi ve \%13.5 Mali îktisat şeklindedir.

\section{Grafik 27. Doktora Tezleri Bilim Dalı Dağılımı}

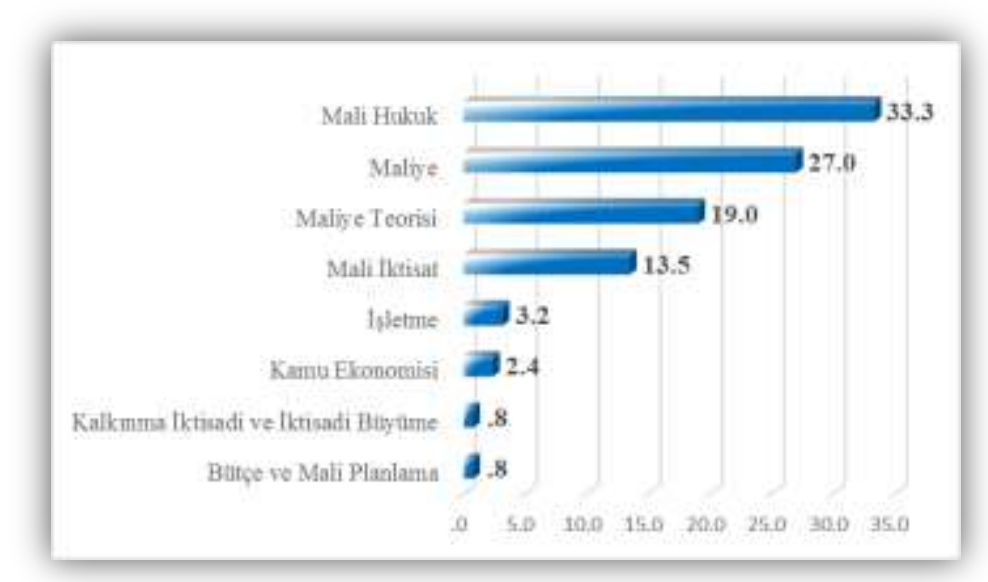

Kaynak: Lisansüstü tezler analiz edilerek yazar tarafından hazırlanmıştır. 
Bilim dalı dağılımında mali hukuk bilim dalının maliye bilim dalından daha fazla olması maliye bilim dalında yapılmış tezler için genellikle sadece ana bilim dalı olarak "maliye" nin belirtilmiş olması ayrıca bilim dalı belirtilmemiş olması neden olarak gösterilebilir.

\subsection{Lisansüstü Tezlerin Bölüm Sayısı, Sayfa Sayısı, Sayfa Aralığı Dağılımı}

Çalışmada analiz edilen lisansüstü tezlerin ağırlıklı olarak en az üç en fazla beş bölümden oluştuğu görülmektedir. Bu bağlamda lisansüstü tezlerin \%67.5'i üç bölümden, \%18.9'u dört bölümden, \%7'si ise beş bölümden oluşmaktadır.

\section{Grafik 28. Lisansüstü Tezlerin Bölüm Sayısı Dağılımı-1}

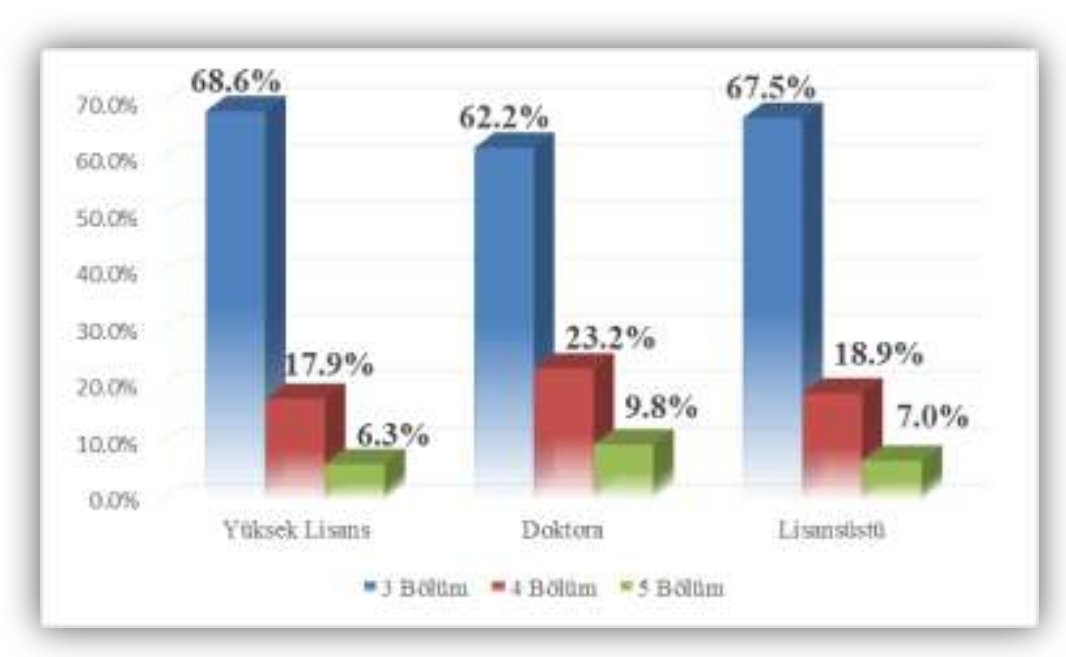

Kaynak: Lisansüstü tezler analiz edilerek yazar tarafından hazırlanmıştır.

Yüksek lisans tezlerinin \%68.6'sı üç bölüm, \%17.9'u dört bölüm, \%6.3'ü beş bölüm iken doktora tezlerinin \%62.2'si üç bölüm, \%23.2'si dört bölüm, \%9.8'i ise beş bölümdür.

Lisansüstü tezlerin sayıca çok az olsa da bir, iki, altı, yedi, sekiz ve on bir bölümden de oluştuğu görülmektedir. Söz konusu verilere ait grafik aşağıda sunulmuştur.

\section{Grafik 29. Lisansüstü Tezlerin Bölüm Sayısı Dağılımı-2}




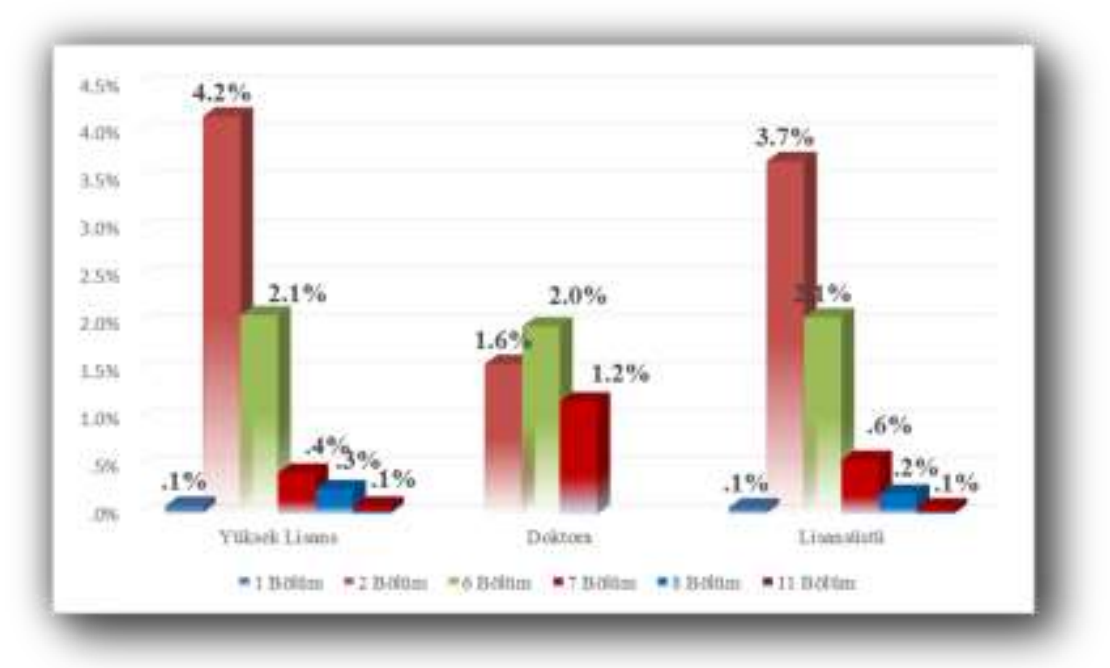

Kaynak: Lisansüstü tezler analiz edilerek yazar tarafından hazırlanmıştır.

Yüksek lisans tezlerinin $\% 0.1^{\prime} i$ bir bölüm, $\% 0.1^{\prime} i$ on bir bölüm, $\% 0.3^{\prime}$ ü sekiz bölüm, \%0.4'ü yedi bölüm, \%2.1'i altı bölüm ve \%4.2'sinin iki bölümden oluştuğu görülmektedir. Doktora tezlerinin ise \%1.2'si yedi bölüm, \%1.6'sı iki bölüm iken \%2'si altı bölümdür. Lisansüstü tezlerin tamamı değerlendirildiğinde tezlerin \%0.1'i bir bölüm, \%0.1'i on bir bölüm, \%0.2'si sekiz bölüm, \%0.6'sı yedi bölüm, \%2.1'i altı bölüm ve \%3.7'si iki bölümden meydana gelmiştir.

Bölüm sayıları genel olarak değerlendirildiğinde lisansüstü çalışmalarda en az bir bölüm en çok on bir bölüm olduğu, dokuz veya on bölümden oluşan çalışma olmadığı, çalışmaların genel olarak üç bölümden oluştuğu söylenebilir. Doktora tezlerinin en az iki en çok yedi bölümden oluştuğu görülmektedir. Ayrıca doktora tezlerinin yüksek lisans tezlerine kıyasla daha çok bölümden oluştuğu ifade edilebilir.

\section{Grafik 30. Lisansüstü Tezlerin Ortalama Sayfa Sayıları}




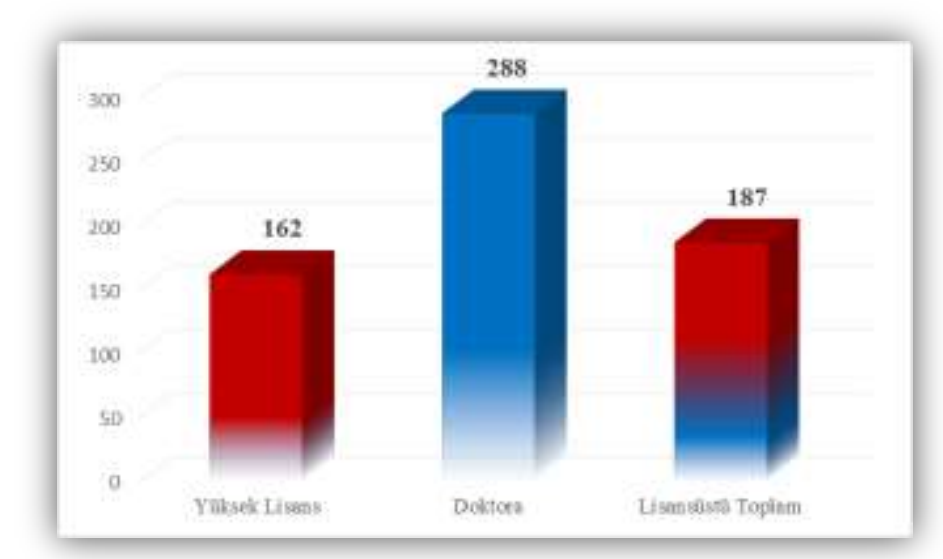

Kaynak: Lisansüstü tezler analiz edilerek yazar tarafından hazırlanmıştır.

Lisansüstü tezlerin sayfa sayısı incelendiğinde Yüksek Lisans tezlerinin ortalama 162 sayfa, doktora tezlerinin ortalama 288 sayfa ve lisansüstü tezlerin tamamının ise ortalama 187 sayfa olduğu belirlenmiştir.

Ayrıca Maliye alanında son on beş yılda tamamlanmış 1714 lisansüstü tez incelendiğinde en az sayfa sayısına sahip Yüksek Lisans tezi 54 sayfa iken en çok 532 sayfadan oluşmaktadır.

\section{Grafik 31. Lisansüstü Tezlerin Sayfa Sayısı, En Az-En Çok}

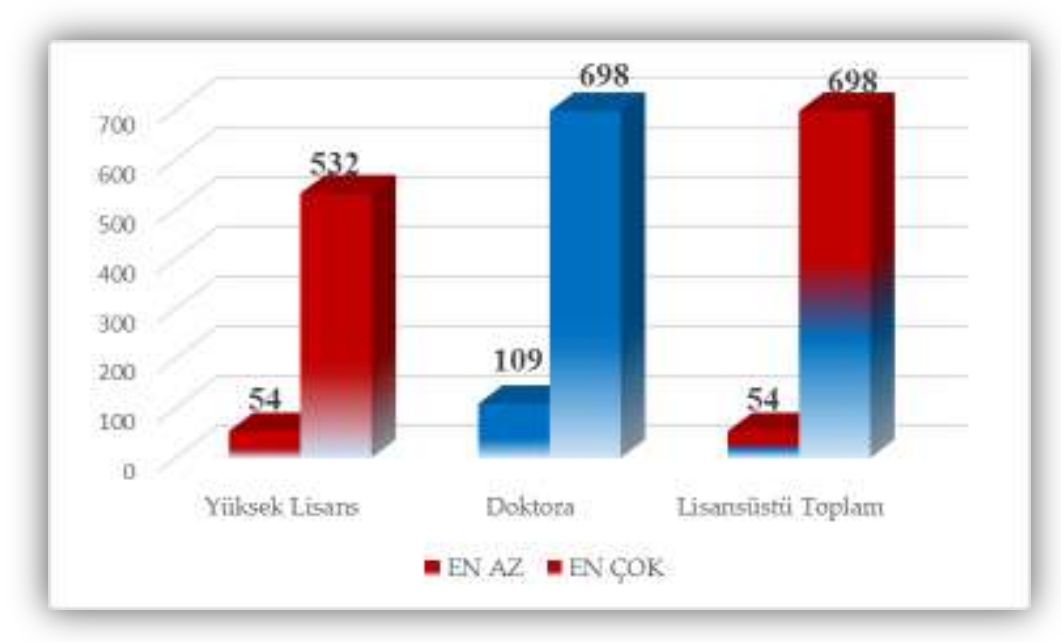

Kaynak: Lisansüstü tezler analiz edilerek yazar tarafından hazırlanmıştır.

Doktora tezleri arasında en düşük sayfa sayısı 109 iken en yüksek sayfa sayısı 698'dir. Dolayısıyla lisansüstü tezlerin en az 54 en çok 698 sayfa olduğu görülmektedir.

Araştırmada ayrıca tezlerin sayfa sayısı aralıkları da belirlenmiş olup aşağıdaki grafikte sunulmuştur.

\section{Grafik 32. Yüksek Lisans Tezlerinin Sayfa Sayısı Aralığı}




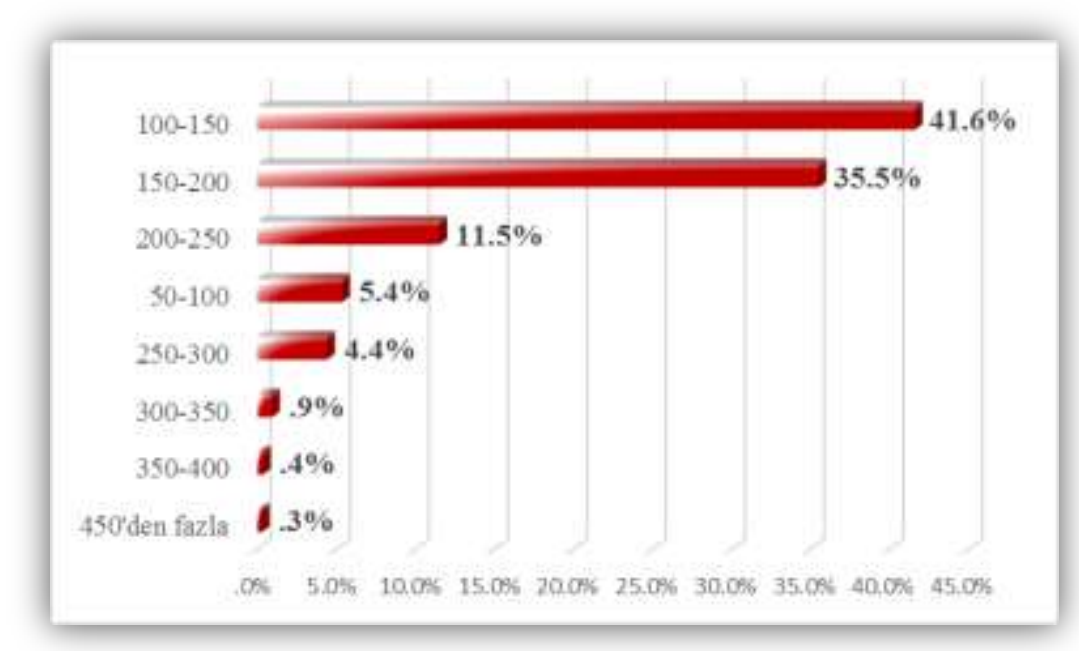

Kaynak: Lisansüstü tezler analiz edilerek yazar tarafından hazırlanmıştır.

Yüksek lisans tezlerinin \%41.6'sı 100-150 sayfa arasında, \%35.5'i 150-200 sayfa arasında iken \%11.5'i 200-250 sayfa arasındadır. Yüksek lisans tezlerinin sadece \%0.7'si 350 sayfadan fazladır.

\section{Grafik 33. Doktora Tezlerinin Sayfa Sayısı Aralığı}

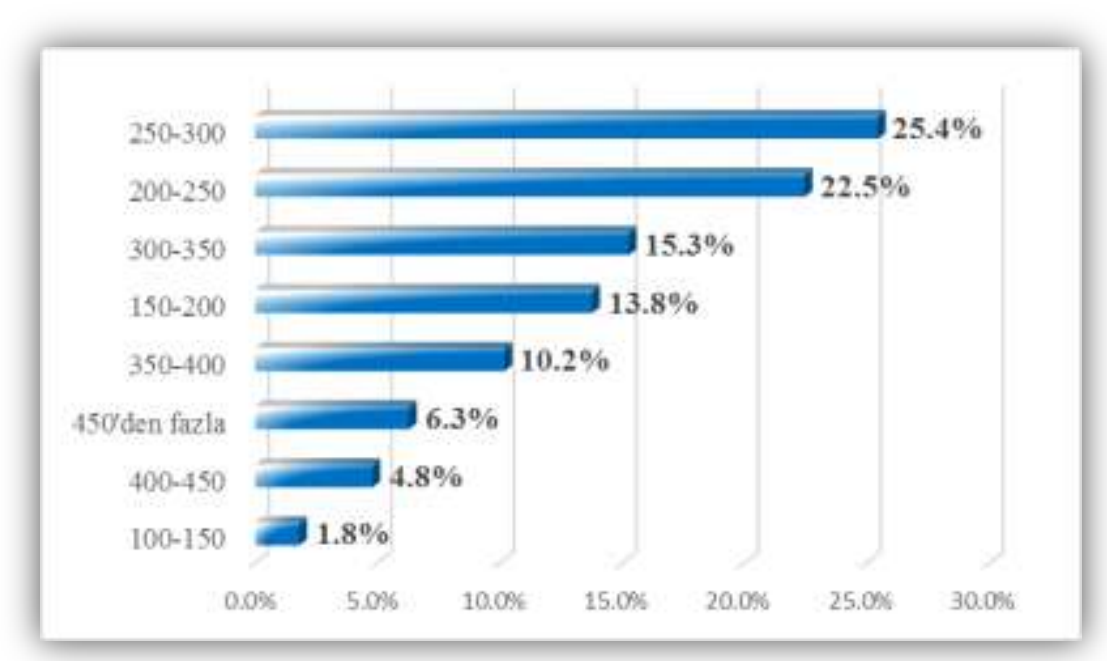

Kaynak: Lisansüstü tezler analiz edilerek yazar tarafından hazırlanmıştır.

Doktora tezlerinin ise \%25.4'ü 250-300 sayfa arasında, \%22.5'i 200-250 sayfa arasında, \%15.3'ü 300-350 sayfa arasında, \%13.8'i 150-200 sayfa, \%10.2'si ise 350-400 sayfa arasındadır. Doktora tezlerinin yüksek lisans tezlerine kıyasla daha çok sayfa sayısından oluştuğu söylenebilir.

\section{Grafik 34. Lisansüstü Tezlerin Sayfa Sayısı Aralığı}




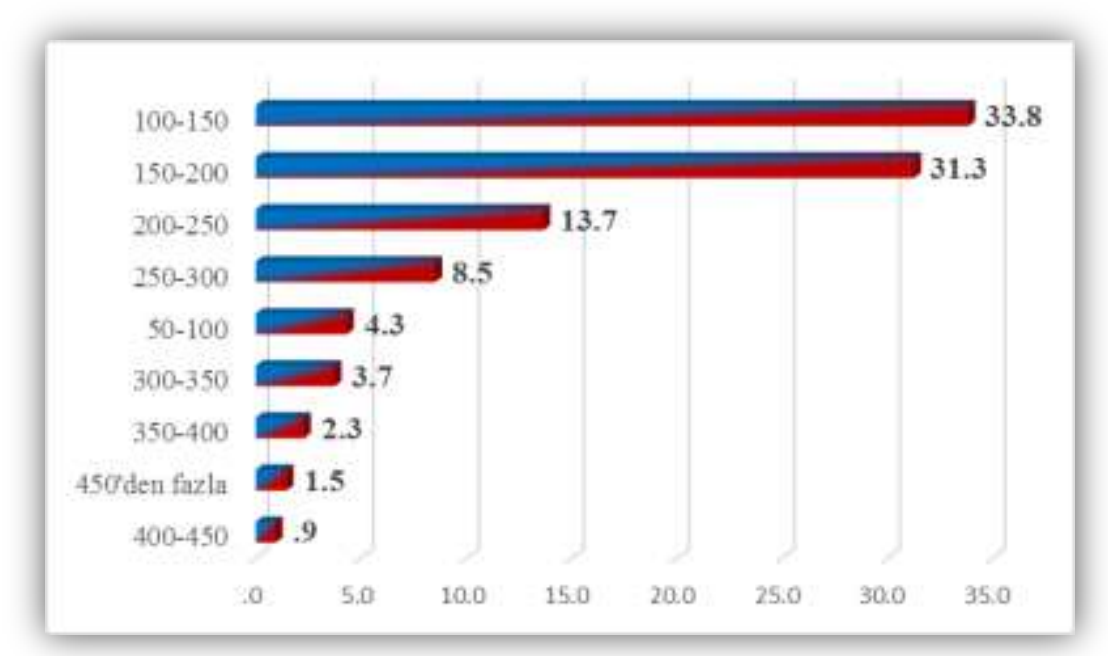

Kaynak: Lisansüstü tezler analiz edilerek yazar tarafından hazırlanmıştır.

Lisansüstü tezlerin tamamı ele alındığında tezlerin \%33.8'inin 100-150 sayfa, \%31.3'ünün 150-200 sayfa, \%13.7'sinin ise 200-250 sayfa arasında olduğu görülmektedir.

\subsection{Lisansüstü Tezlerin Anahtar Kelime Dağılımı ve Kelime Bulutları}

Yüksek Lisans tezlerinde kullanılan anahtar kelimelerin dağılımı aşağıdaki grafikte gösterilmektedir.

\section{Grafik 35. Yüksek Lisans Tezlerinde En Çok Kullanılan Anahtar Kelimeler}

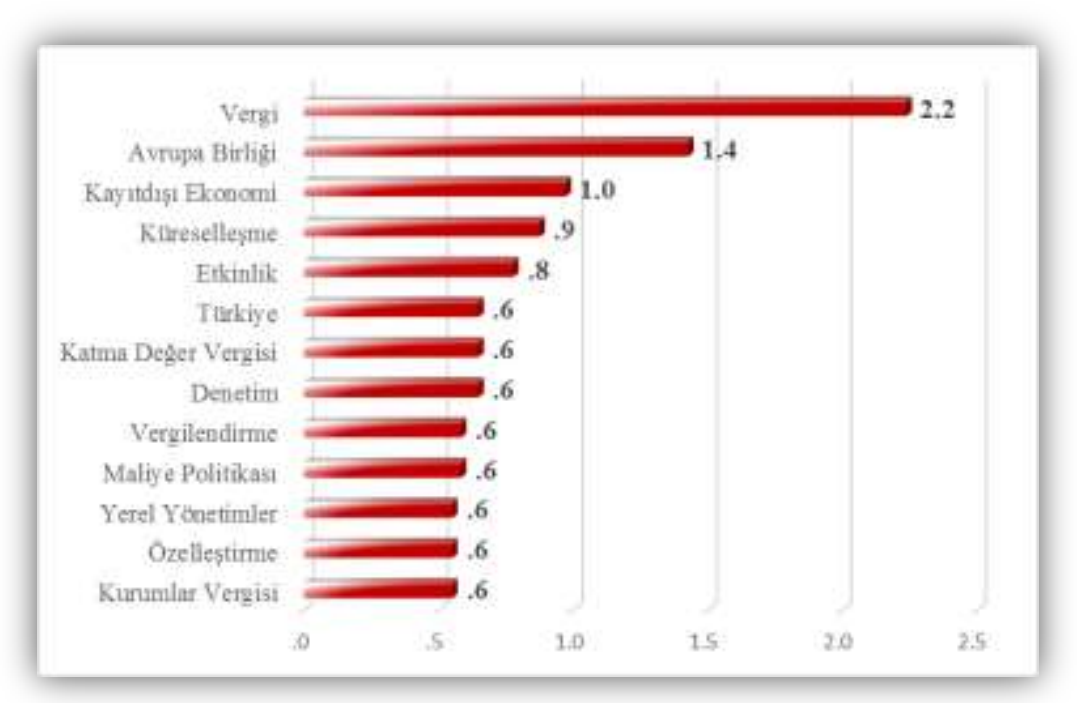

Kaynak: Lisansüstü tezler analiz edilerek yazar tarafından hazırlanmıştır.

Yüksek Lisans tezlerinde sırasıyla en çok "Vergi", "Avrupa Birliği", "Kayıtdışı Ekonomi", "Küreselleşme" ve "Etkinlik" anahtar kelimeleri kullanılmıştır. 


\section{Grafik 36. Doktora Tezlerinde En Çok Kullanılan Anahtar Kelimeler}

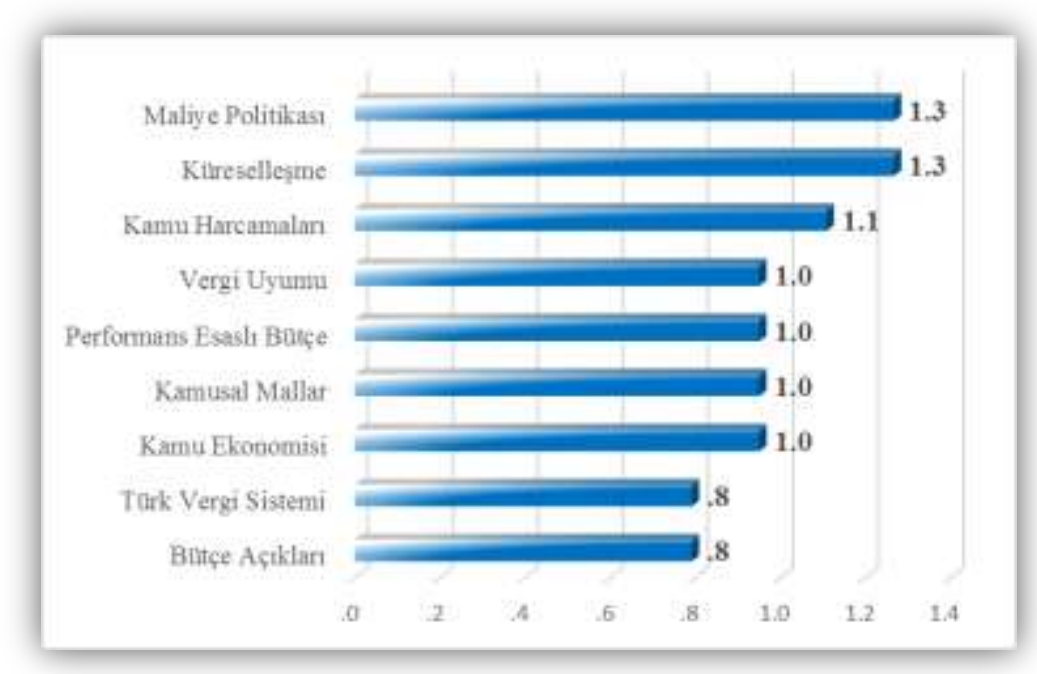

Kaynak: Lisansüstü tezler analiz edilerek yazar tarafından hazırlanmıştır.

Doktora tezlerinde sırasıyla en çok "Maliye Politikası", "Küreselleşme", "Kamu Harcamaları"anahtar kelimeleri kullanılmıştır.

\section{Grafik 37. Lisansüstü Tezlerde En Çok Kullanılan Anahtar Kelimeler}

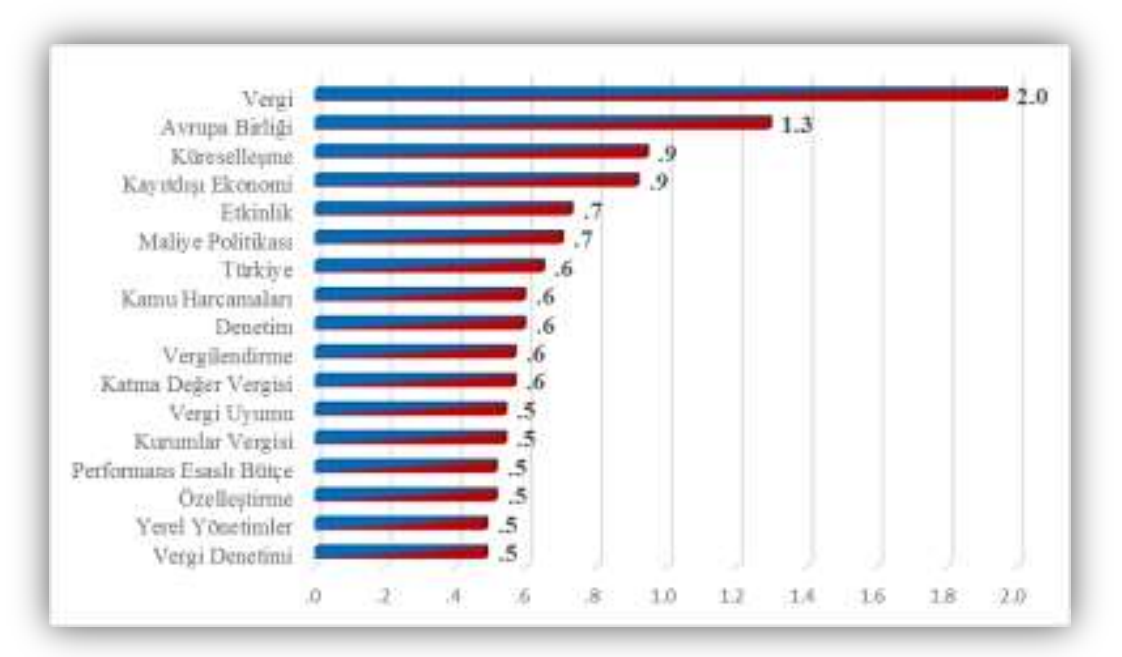

Kaynak: Lisansüstü tezler analiz edilerek yazar tarafından hazırlanmıştır.

Yüksek Lisans tezlerine benzer şekilde Lisansüstü tezlerin tamamında da sırasıyla en çok kullanılan beş anahtar kelime "Vergi", "Avrupa Birliği", "Kayıtdışı Ekonomi", "Küreselleşme" ve "Etkinlik" şeklindedir.

Lisansüstü tezlerde anahtar kelimeler grubunda en çok kullanılan 50 kelime ile oluşturulan kelime bulutu aşağıda gösterilmektedir. 


\section{Grafik 38. Anahtar Kelimelere ilişkin Kelime Bulutu}

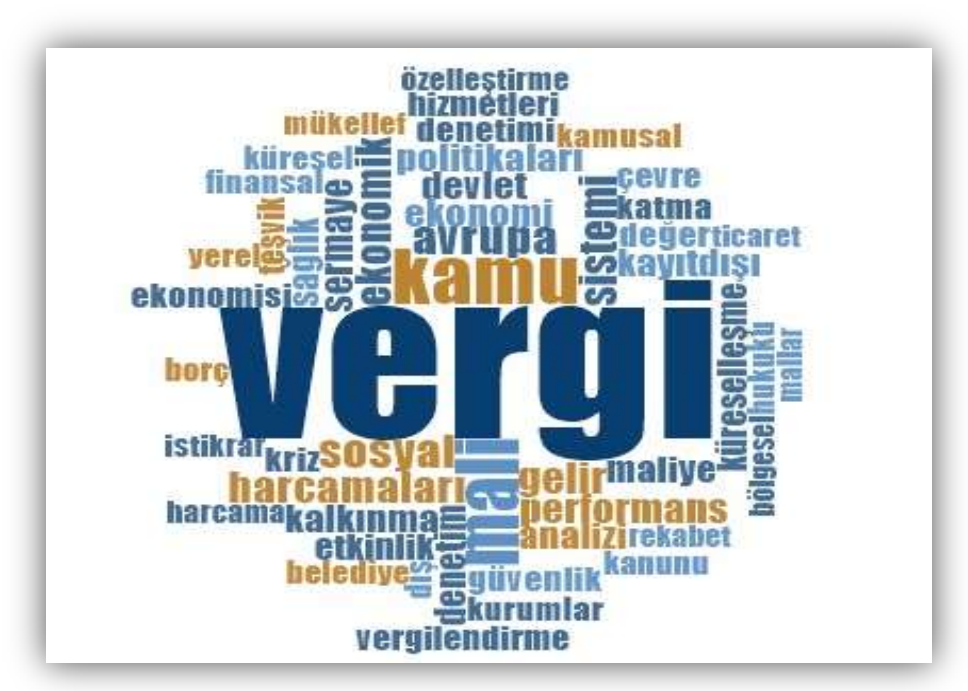

Kaynak: Lisansüstü tezler analiz edilerek yazar tarafından hazırlanmıştır.

Lisansüstü tezlerin anahtar kelimelerinde en çok kullanılan 5 kelime ve kelimelerin tekrarı şu şekildedir: "Vergi (536)", "Kamu (149)", "Mali (147)", "Avrupa (70)", "Sosyal (70)".

\subsection{Lisansüstü Tezlerin Başlıklarında ve Özetlerinde Kullanılan Kelimelerin Dağılımı}

Lisansüstü tezlerin başlıklarında en çok kullanılan 5 kelime ve kelimelerin frekansı "Vergi (487)", "Türkiye'de (330)", "Örneği (191)", "Değerlendirilmesi (185)", "Kamu (179)" şeklindedir.

\section{Grafik 39. Lisansüstü Tezlerin Başlıklarına Illişkin Kelime Bulutu}

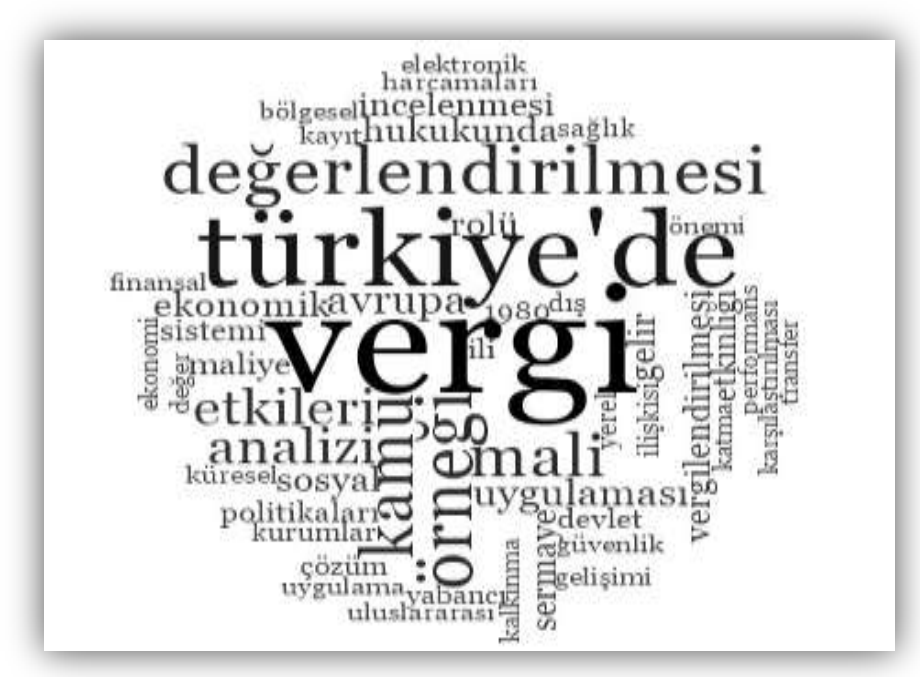

Kaynak: Lisansüstü tezler analiz edilerek yazar tarafından hazırlanmıştır.

Lisansüstü tezlerin özetlerinde en çok kullanılan 5 kelime ve kelimelerin frekansı ise "Vergi (3972)", "Kamu (1786)", "Ekonomik (1366)", "Mali (1210)", "Sosyal (874)" 
şeklindedir. Özetlerde en çok kullanılan 50 kelime ile oluşturulan kelime bulutu aşağıdaki grafikte sunulmuştur.

\section{Grafik 40. Lisansüstü Tezlerin Özetlerine Illişkin Kelime Bulutu}

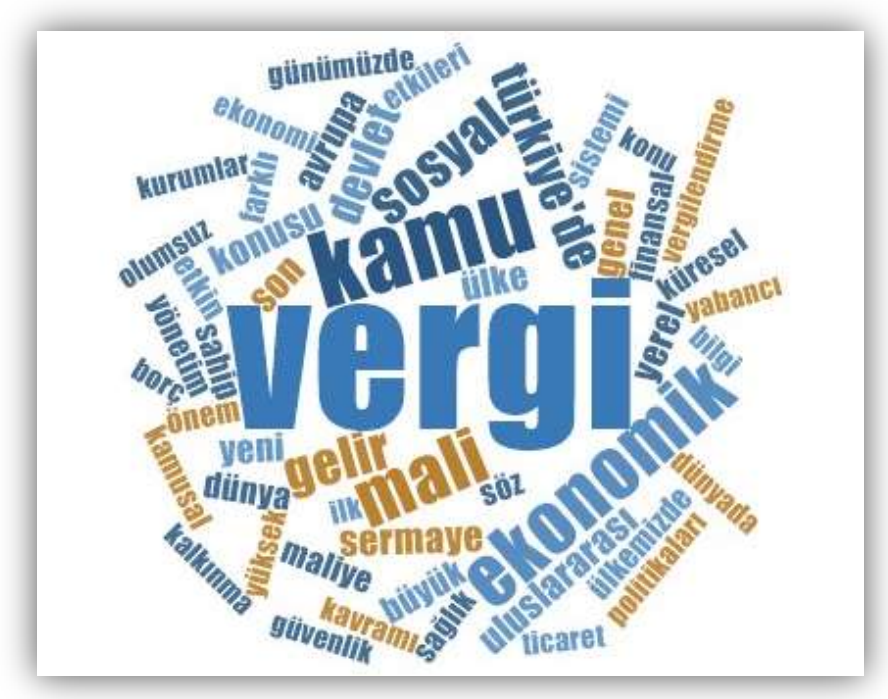

Kaynak: Lisansüstü tezler analiz edilerek yazar tarafından hazırlanmıştır.

\subsection{Lisansüstü Tezlerin İçerik ve Yöntemlerine Dair Dağılım}

Çalışmanın bu kısmında lisansüstü tezlerin teorik veya ampirik olma durumu, ampirik tezlerin hangi yöntemi içerdiği, ekonometrik tezlerde en çok kullanılan yöntemler ve testlerin neler olduğu, anket uygulaması içeren tezlerde en sık hangi illerde anket yapıldığı ve örneklem büyüklüğü gibi tezlerin içeriğine dair analiz yapılacaktır.

\section{Grafik 41. Lisansüstü Tezlerin Ampirik Olma Durumu}

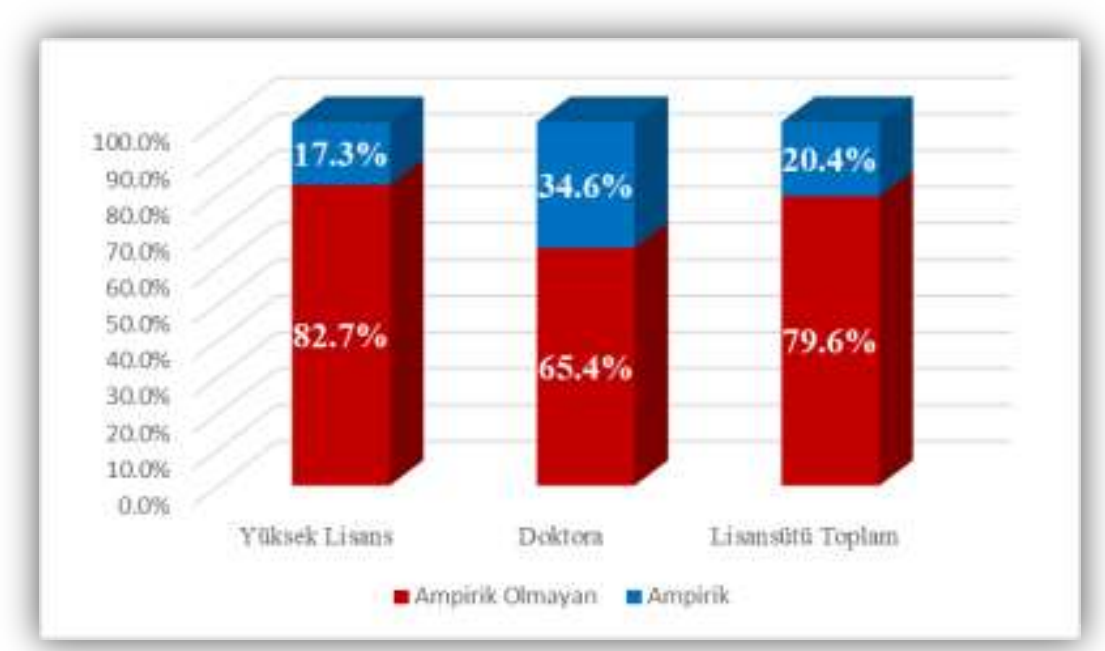

Kaynak: Lisansüstü tezler analiz edilerek yazar tarafından hazırlanmıştır.

Lisansüstü tezlerin \%20.4'ü, yüksek lisans tezlerinin \%17.3'ü, doktora tezlerinin ise \%34.6'sının ampirik uygulama içerdiği görülmektedir. Bu bağlamda doktora 
tezlerinin yüksek lisans tezlerine kıyasla daha çok uygulama içerdiği söylenebilir. Ancak tezlerin geneline bakıldığında \%80'inin uygulama içermediği ve bunun da belki maliye alanı için yetersiz bir oran olduğu ifade edilebilir.

\section{Grafik 42. Yüksek Lisans Tezlerinin Yıllara Göre Ampirik Olma Durumu}

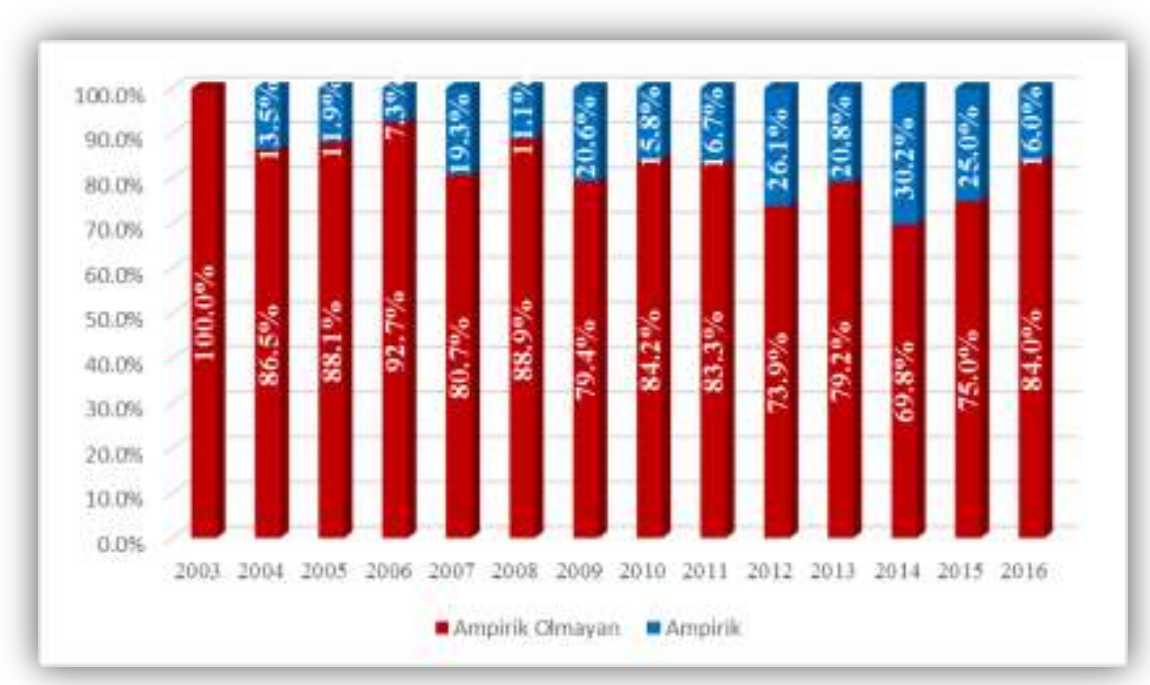

Kaynak: Lisansüstü tezler analiz edilerek yazar tarafından hazırlanmıştır.

Yüksek lisans tezlerinin özellikle 2010 yılı sonrasında ampirik uygulama içerme durumunda artış olduğu görülmektedir. 2014 yılında yazılan yüksek lisans tezlerinin yaklaşık \%30'u uygulama içermektedir.

\section{Grafik 43. Doktora Tezlerinin Yıllara Göre Ampirik Olma Durumu}

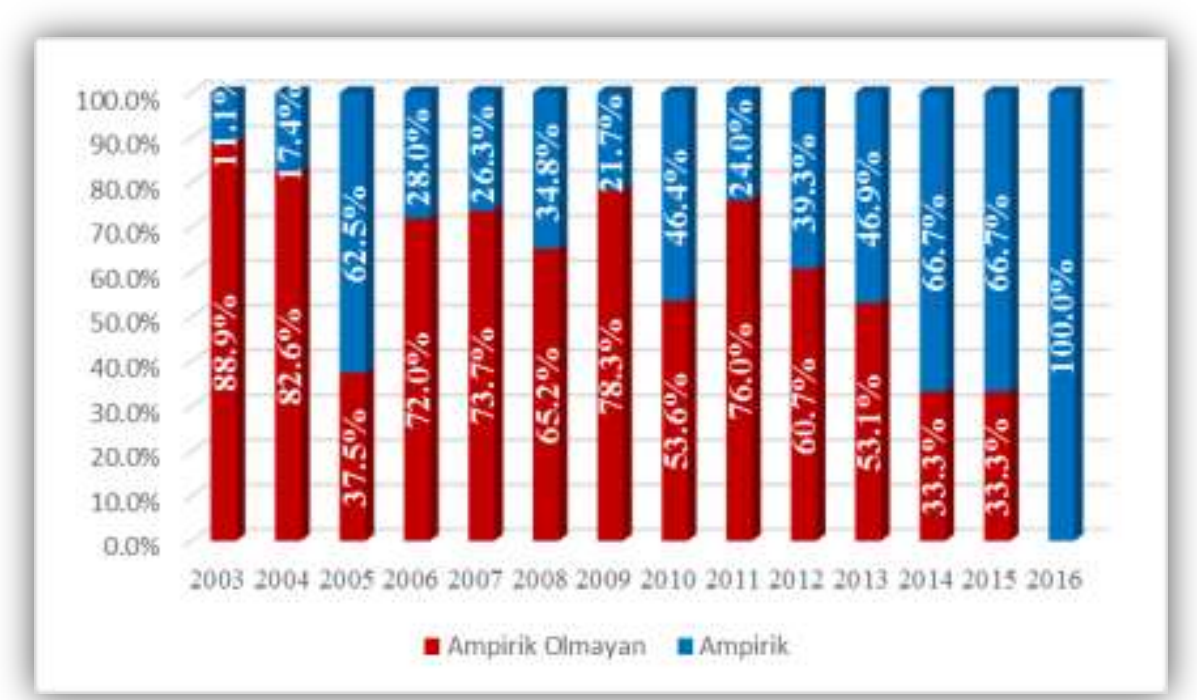

Kaynak: Lisansüstü tezler analiz edilerek yazar tarafından hazırlanmıştır. 
Doktora tezlerinin özellikle 2011 yılı sonrasında ampirik uygulama içerme durumunda artış olduğu görülmektedir. 2016 yılında yazılan doktora tezlerinin tamamı uygulama içermektedir.

\section{Grafik 44. Lisansüstü Tezlerin Yıllara Göre Ampirik Olma Durumu}

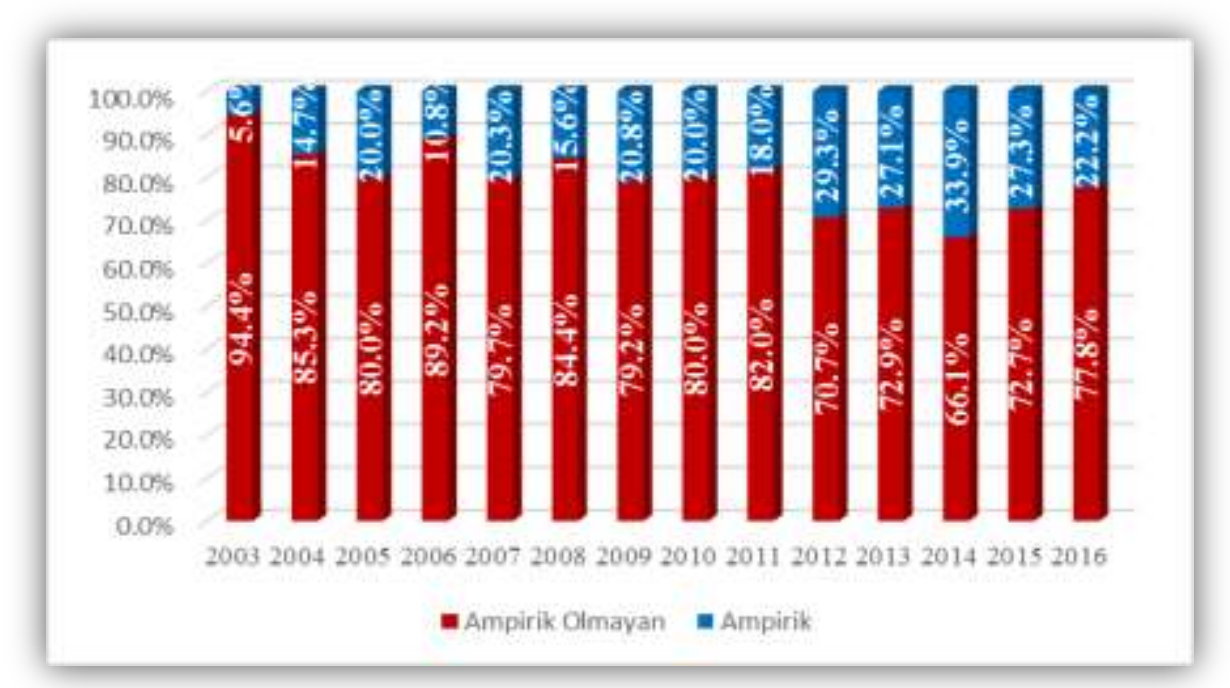

Kaynak: Lisansüstü tezler analiz edilerek yazar tarafından hazırlanmıştır.

Lisansüstü tezlerin tamamı ele alındığında ise son beş yılda ampirik uygulama içerme durumunda artış olduğu görülmektedir. Özellikle 2014 yılında tamamlanan lisansüstü tezlerin yaklaşık \%34'ü uygulama içermektedir. Dolayısıyla maliye alanında yazılan tezlerin özellikle son yıllarda uygulamaya yönelik olduğu belirtilebilir.

Aşağıdaki grafikteki ana bilim dallarına göre tezlerin ampirik olma durumu gösterilmektedir.

\section{Grafik 45. Ana Bilim Dalına Göre Tezlerin Ampirik Olma Durumu}

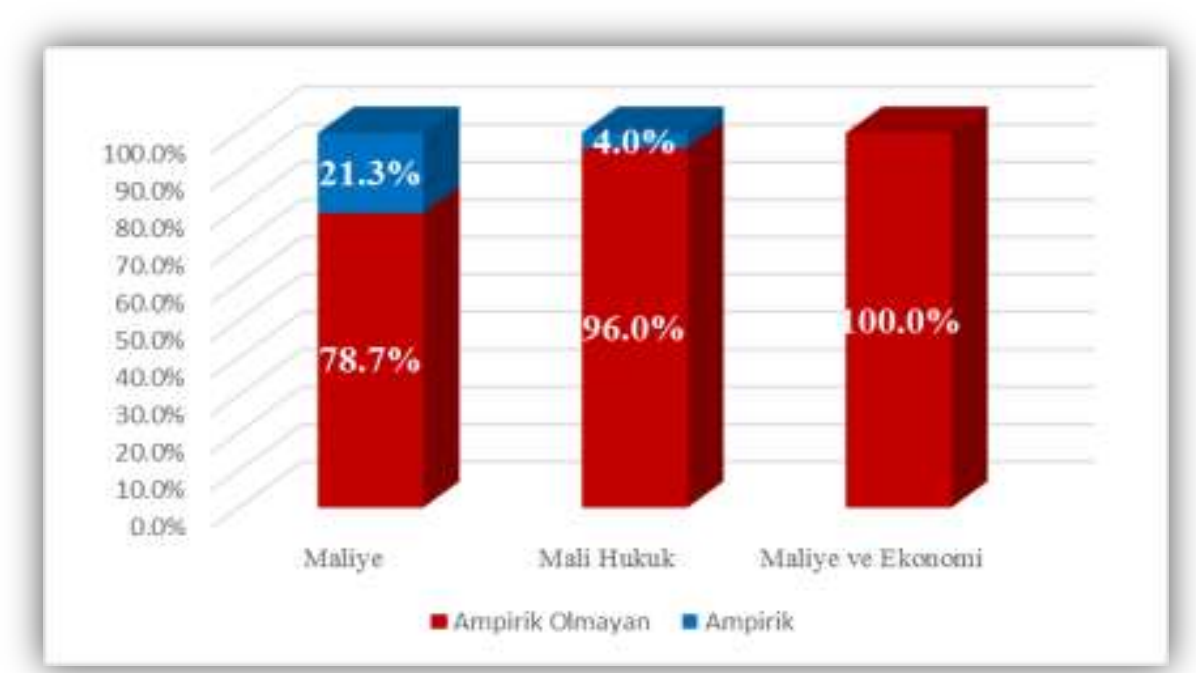

Kaynak: Lisansüstü tezler analiz edilerek yazar tarafından hazırlanmıştır. 
Maliye ana bilim dalındaki tezlerin \%21.3'ü uygulama içermekteyken mali hukuk ana bilim dalında tamamlanmış tezlerin ise sadece \%4'ü uygulama içermektedir. Mali hukuk alanında yapılan çalışmalarda uygulama yapılmasının zor olduğu kabul edilebilir olsa da bu derece düşük bir oranda uygulamalı çalışma içeriyor olması eleştirilebilir. Ayrıca uygulama yapılabilmesine daha elverişli alanlar olsa da maliye ve ekonomi ana bilim dalında yapılan çalışmaların hiçbiri uygulama içermemektedir.

Ampirik çalışmaların lisansüstü tezlere göre dağılımı ise şu şekildedir:

$\checkmark$ Yüksek lisans tezlerinin \%51.8'i anket, \%20.1'i ekonometrik, \%14.1'i istatistiksel, $\% 5.5^{\prime}$ i mülakat ve \%8.5'i örnek olay şeklinde uygulama içermektedir.

$\checkmark$ Doktora tezlerinin \%33'ü anket, \%52.3'ü ekonometrik, \%11.4'ü istatistiksel, \%2.3'ü mülakat ve \%1.1'i örnek olay şeklinde uygulama içermektedir.

$\checkmark$ Lisansüstü tezlerinin tamamında ise \%46'sı anket, \%30'u ekonometrik, \%13.2'si istatistiksel, \%4.5'i mülakat ve \%6.3'ü örnek olay şeklinde uygulama içermektedir.

\section{Grafik 46. Ampirik Çalışmaların Dağılımı}

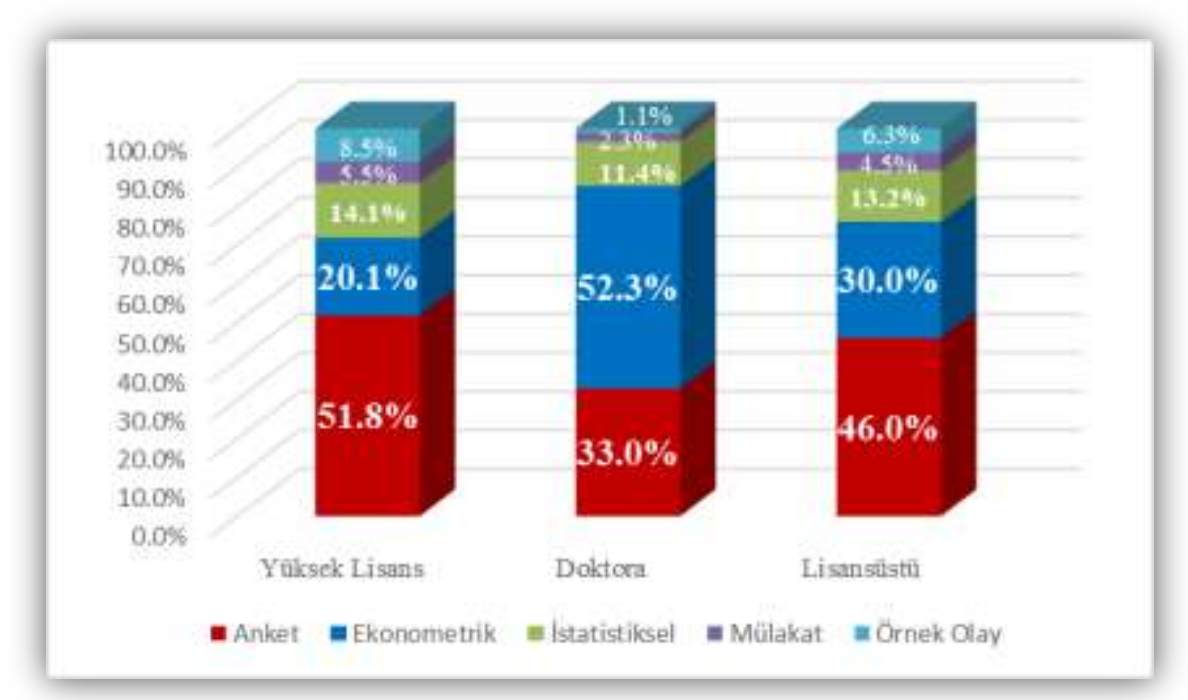

Kaynak: Lisansüstü tezler analiz edilerek yazar tarafından hazırlanmıştır.

Sonuç olarak lisansüstü tezlerde ampirik uygulama türlerinden en çok anket ve ekonometrik uygulamaların tercih edildiği görülmektedir. Doktora tezlerinde daha çok ekonometrik çalışmaların yüksek lisans tezlerinde ise anket uygulamasının daha çok yer aldığı ifade edilebilir. 


\section{Grafik 47. Ampirik Çalışma Türlerinin Yıllara Göre Dağılımı}

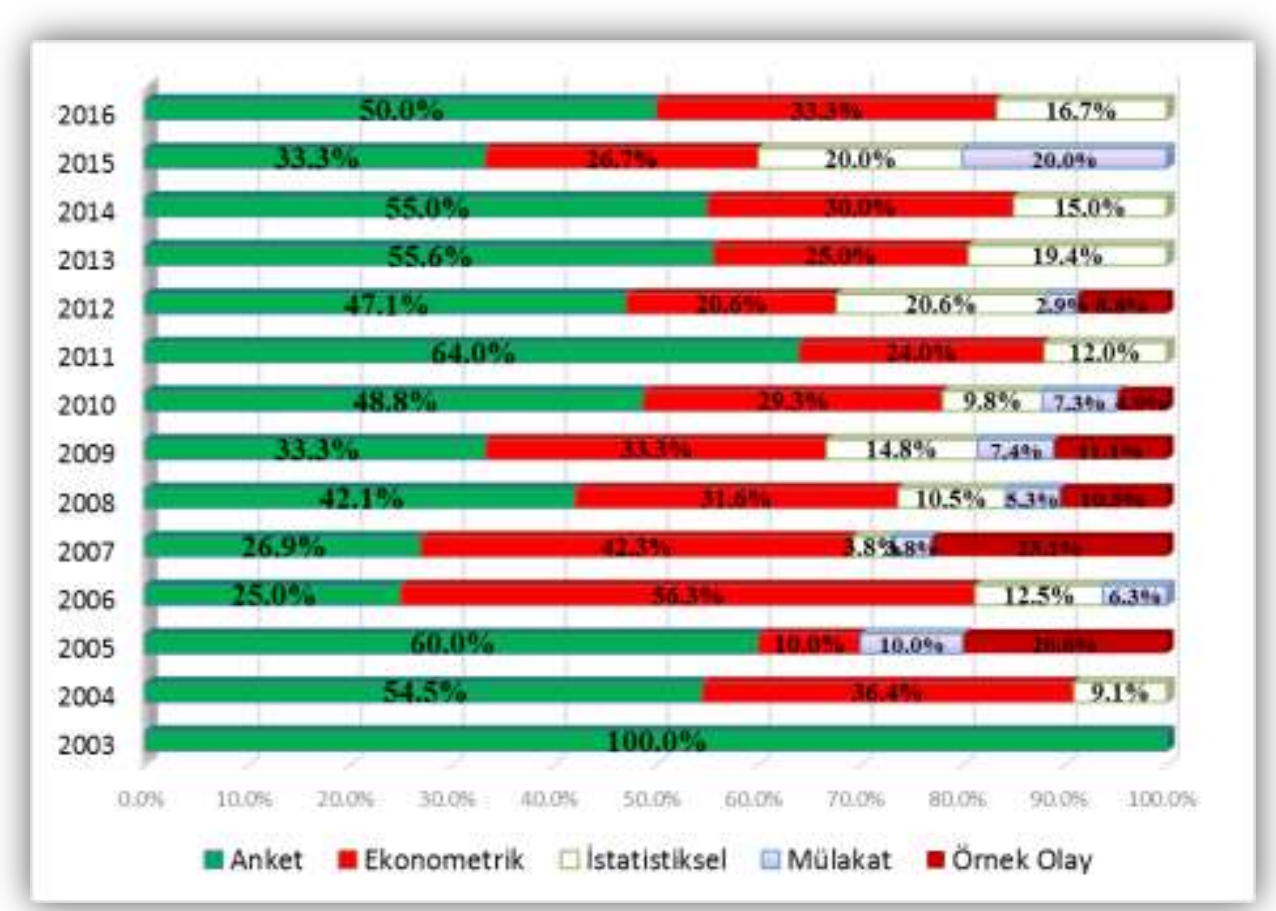

Kaynak: Lisansüstü tezler analiz edilerek yazar tarafından hazırlanmıştır.

Ampirik çalışma türlerinin yıllar itibarıyla değerlendirilmesi halinde dalgalanmalar olsa da son yıllarda istatistiksel ve mülakat içeren çalışmalarda oransal olarak artış olduğu söylenebilir.

\section{Grafik 48. Lisansüstü Ekonometrik Tezlerin Dağılımı}

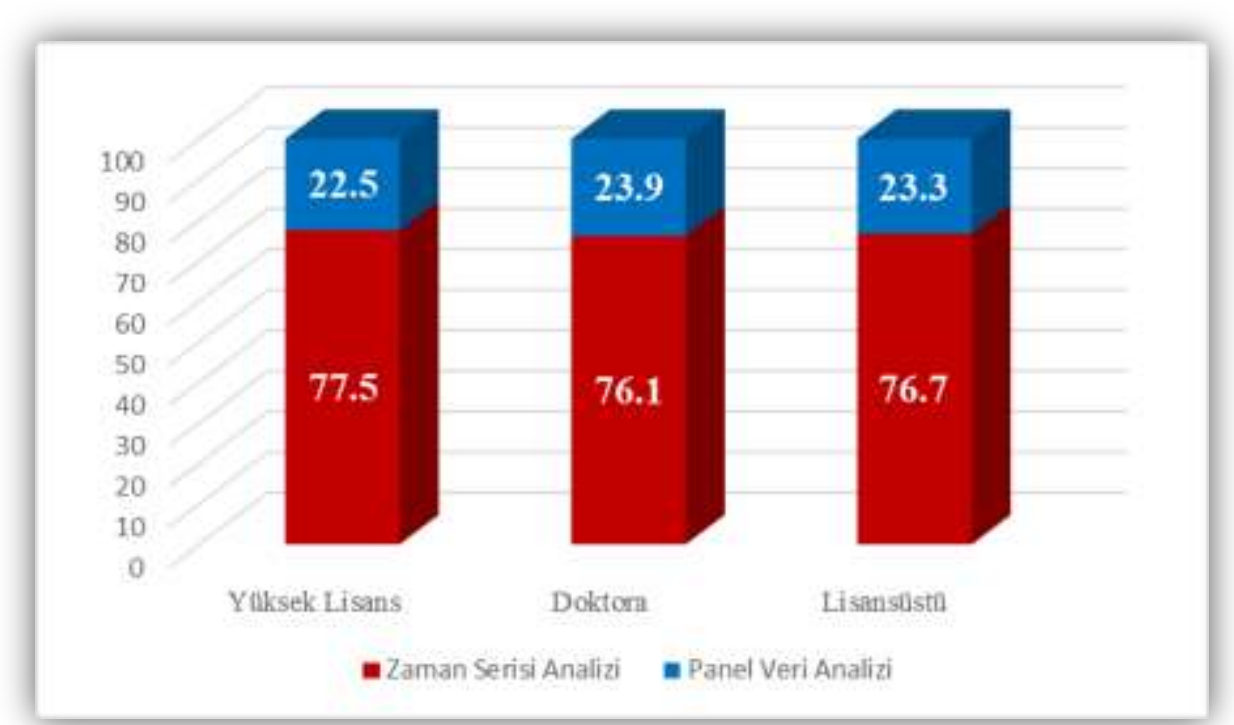

Kaynak: Lisansüstü tezler analiz edilerek yazar tarafından hazırlanmıştır. 
Ekonometrik çalışmaların zaman serisi ve panel veri analizi içeren çalışmalar şeklinde ikiye ayrılması halinde maliye alanında hem yüksek lisans hem de doktora tezlerinde yaklaşık \%76-77 gibi bir oranla zaman serisi analizinin kullanıldığı görülmektedir.

\section{Grafik 49. Zaman Serisi Analizlerinde En Sık Kullanılan Test ve Yöntemler}

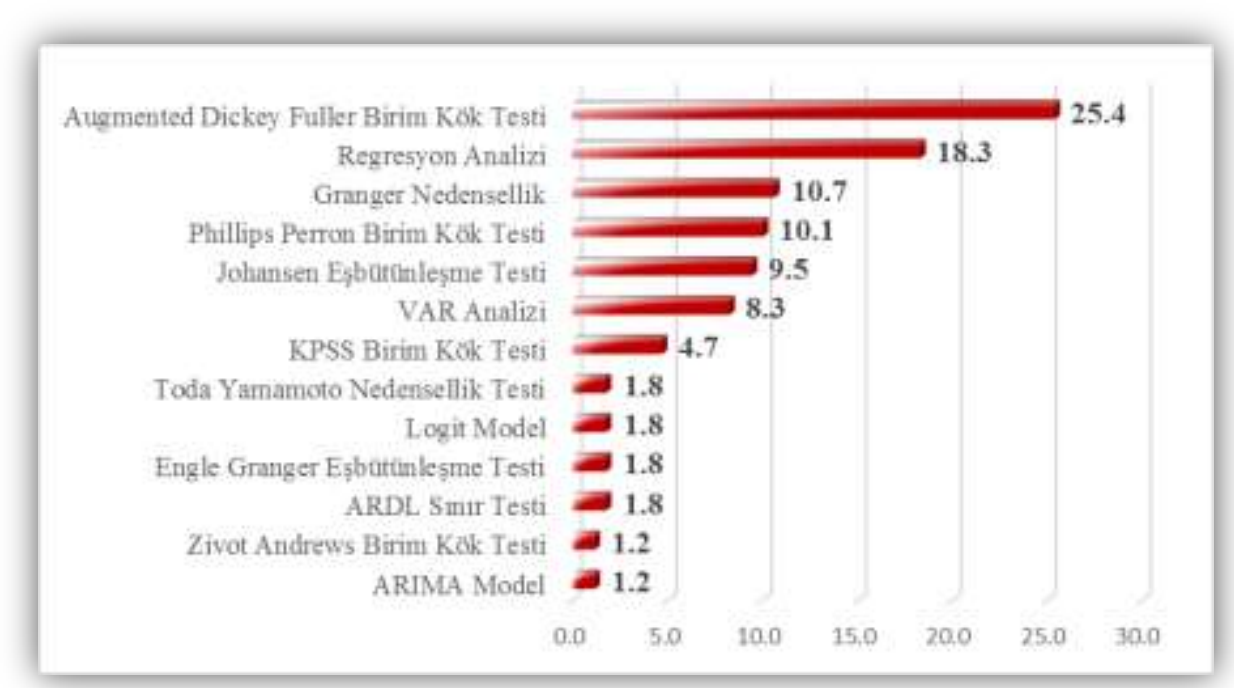

Kaynak: Lisansüstü tezler analiz edilerek yazar tarafından hazırlanmıştır.

Zaman serisi analizi içeren çalışmalar değerlendirildiğinde en sık kullanılan test ve yöntemlerin Augmented Dickey Fuller birim kök testi, Regresyon analizi, Granger nedensellik testi, Phillips Perron birim kök testi, Johansen eşbütünleşme testi, VAR analizi ve KPSS birim kök testi olduğu görülmektedir.

\section{Grafik 50. Panel Veri Analizlerinde En Sık Kullanılan Test ve Yöntemler}

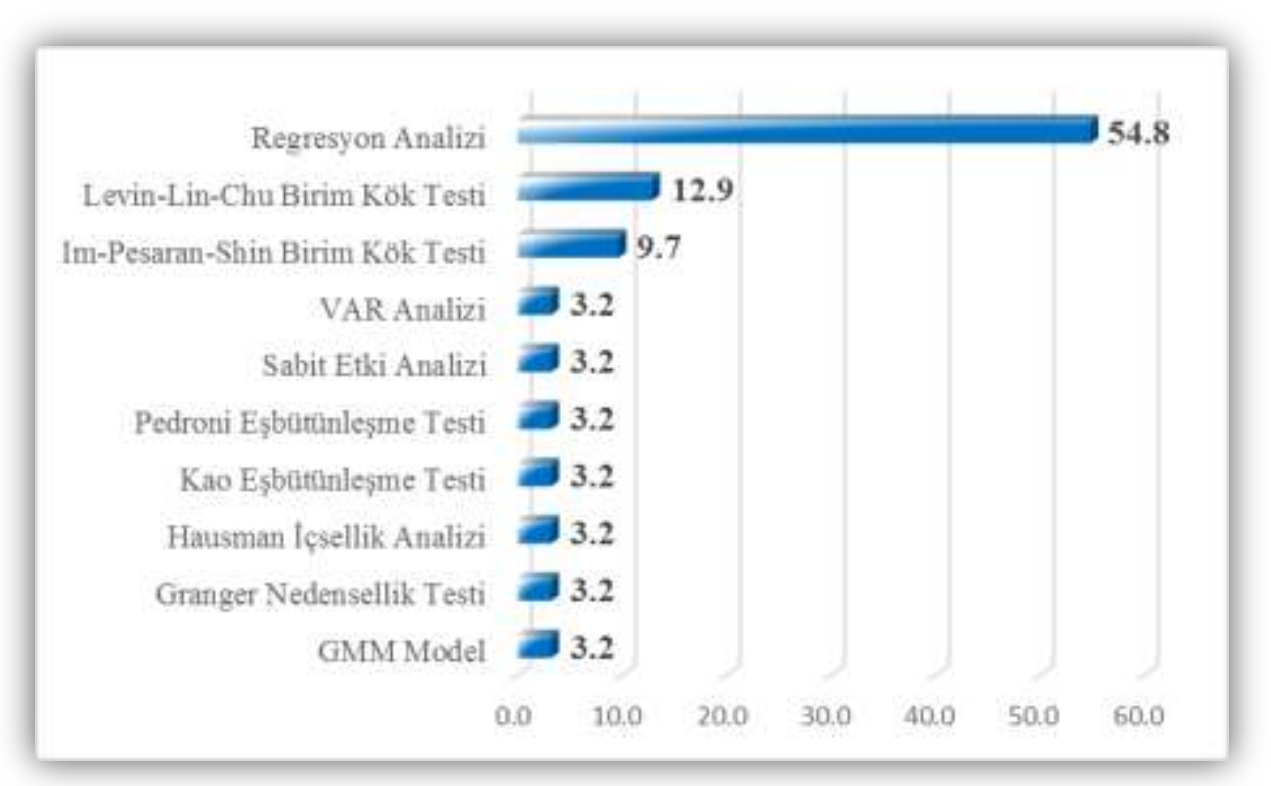

Kaynak: Lisansüstü tezler analiz edilerek yazar tarafından hazırlanmıştır. 
Panel veri analizi içeren çalışmalar değerlendirildiğinde ise en sık kullanılan test ve yöntemlerin Regresyon analizi, Levin Lin Chu birim kök testi ve Im Peseran Shin birim kök testi olduğu görülmektedir.

\section{Grafik 51. İstatistiksel Analizlerde En Sık Kullanılan Test ve Yöntemler}

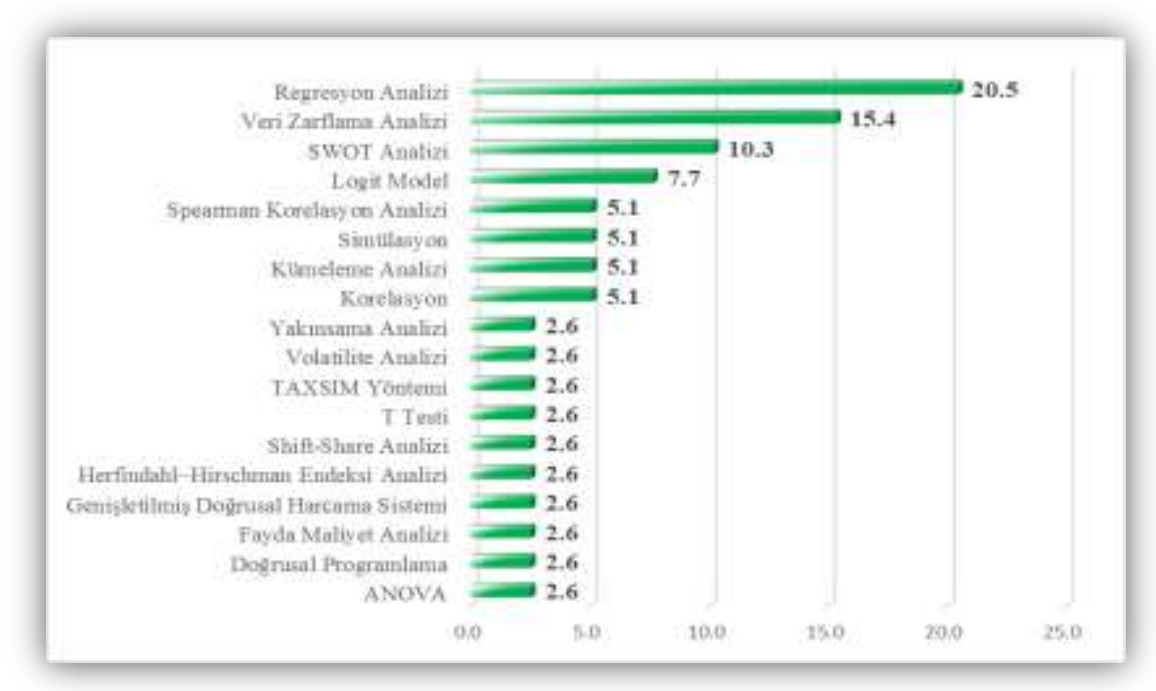

Kaynak: Lisansüstü tezler analiz edilerek yazar tarafından hazırlanmıştır.

İstatistiksel analiz içeren çalışmalar değerlendirildiğinde en sık kullanılan test ve yöntemlerin Regresyon analizi, veri zarflama analizi ve Swot analizi olduğu görülmektedir.

Grafik 52. Anket Uygulamalarının En Sık Yapıldığı iller

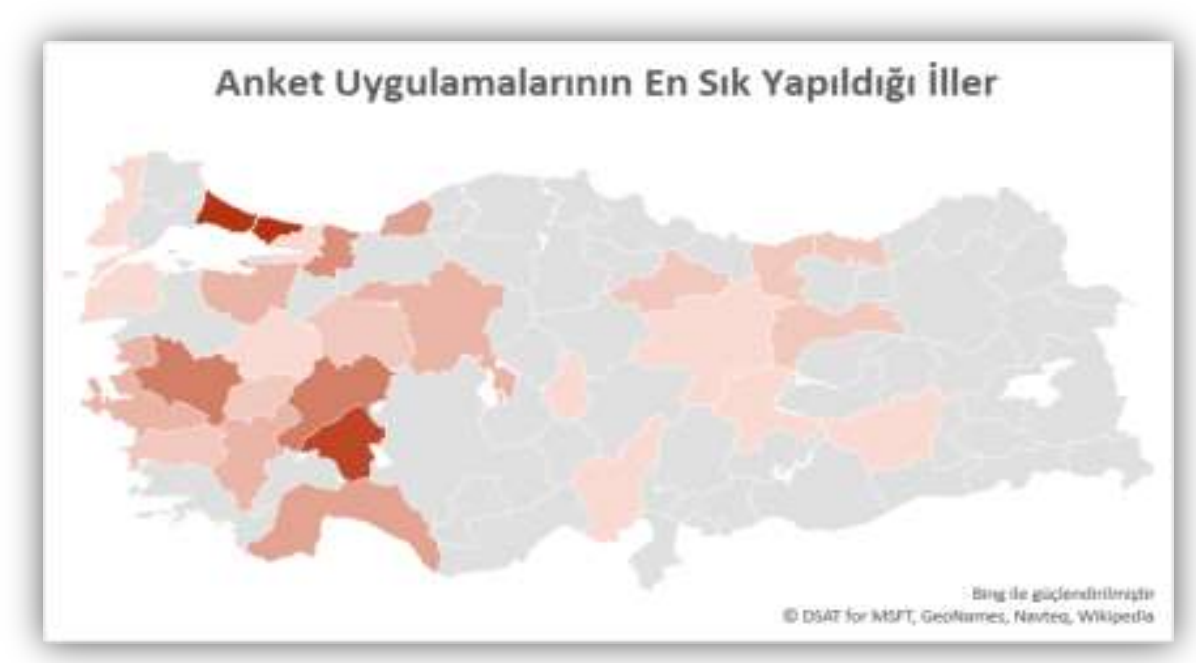

Kaynak: Lisansüstü tezler analiz edilerek yazar tarafından hazırlanmıştır.

Anket uygulaması içeren çalışmalarda anketlerin en çok yapıldığı beş il sırasıyla İstanbul, Isparta, Manisa, Afyon, Sakarya şeklindedir. 


\section{Grafik 53. Ortalama Anket Sayısı}

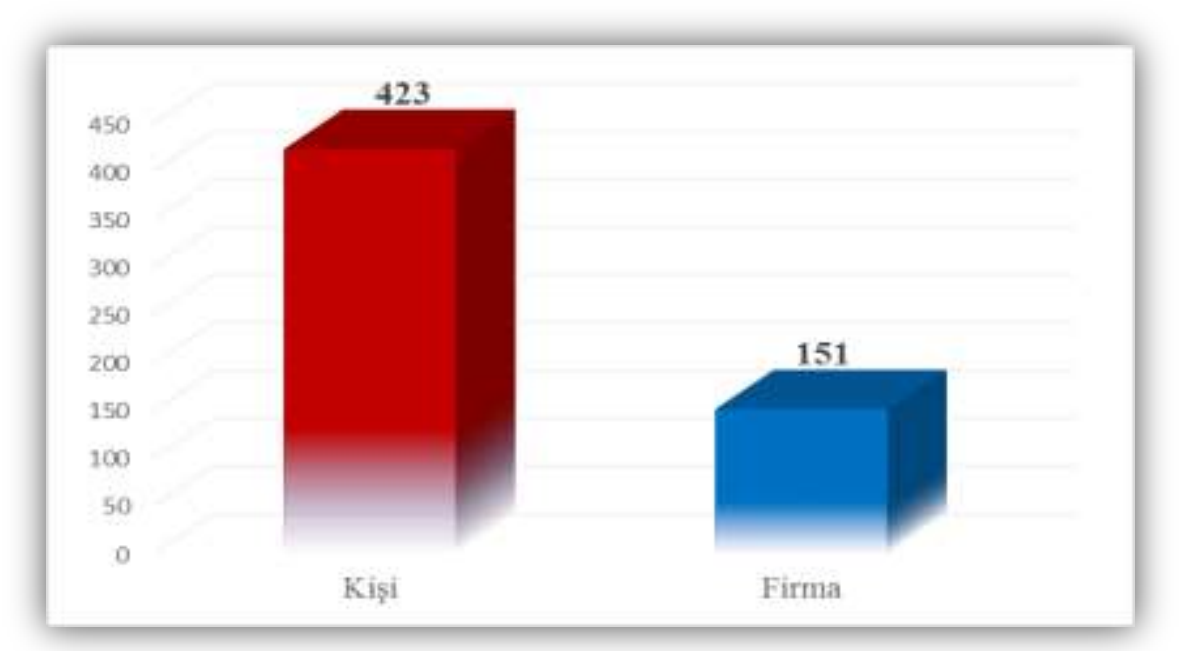

Kaynak: Lisansüstü tezler analiz edilerek yazar tarafından hazırlanmıştır.

Ayrıca örneklem büyüklüğü konu itibarıyla farklılık gösterebilse de anket uygulaması içeren çalışmalarda kişi (mükellef) ile yapılan ortalama anket sayısı 423 iken firma ile yapılan anket sayısının ise ortalama 151 olduğu belirlenmiştir.

\section{Sonuç}

Bu araştırma 2003-2017 yılları arasında yapılan maliye alanındaki lisansüstü tezlerin çeşitli değişkenler açısından incelenmesi amacıyla yapılmıştır. Bu bağlamda 1714 lisansüstü tez doküman incelemesi yöntemi ile analiz edilmiştir. Çalışmada analiz edilen tezlerin \%19.5'i doktora, \%80.5'i yüksek lisans tezidir. Yüksek lisans tezlerinin \%16.6'sı izinsiz veya indirilemez durumda iken bu oran doktora tezleri için \%24 düzeyindedir. Yüksek lisans tez yazarlarının daha çok erkek olduğu, cinsiyet karşılaştırmasında oran olarak kadınların doktora çalışmalarına nazaran yüksek lisans çalışmalarında daha çok yer aldığı görülmektedir. Çalışma sonucunda yüksek lisans tezlerinin en çok sırasıyla 2010, 2006 ve 2011 yıllarında en az 2003, 2016 ve 2004 yıllarında; doktora tezlerinin ise en çok sırasıyla 2013, 2006, 2012 ve 2010 yıllarında en az 2005, 2016, 2003 ve 2015 yıllarında yazıldığı sonucuna ulaşılmıştır.

Son on beş yılda Maliye alanında yapılan yüksek lisans ve doktora tezlerinin sırasıyla en çok Marmara Üniversitesi, İstanbul Üniversitesi ve Dokuz Eylül Üniversitesi'nde tamamlandığı görülmektedir. Maliye alanında yüksek lisans yapanların en çok sırasıyla Uludağ Üniversitesi, Karadeniz Teknik Üniversitesi ve Süleyman Demirel Üniversitesi; doktora yapanların ise en çok sırasıyla İstanbul Üniversitesi, Anadolu Üniversitesi ve Uludağ Üniversitesi lisans mezunu oldukları görülmektedir. Ayrıca Maliye alanında yüksek lisans yapanların en çok sırasıyla Maliye, İşletme, İktisat ve Kamu Yönetimi bölümlerinden; doktora yapanların ise en çok sırasıyla Maliye, İktisat, Hukuk, İşletme, Kamu Yönetimi, Turizm ve Otel İşletmeciliği, Tıp Fakültesi, Ekonometri bölümlerinden mezun oldukları bulgusu elde edilmiştir. 
Maliye alanında son on beş yılda tamamlanan yüksek lisans tezlerinde en çok danışmanlık yapan üç öğretim üyesinin sırasıyla Prof. Dr. Salim Ateş Oktar, Prof. Dr. Şükrü Kızılot ve Prof. Dr. İbrahim Atilla Acar; doktora tezlerinde en çok danışmanlık yapan öğretim üyelerinin sırasıyla Yrd. Doç. Dr. Ahmet Bumin Doğrusöz, Prof. Dr. Ömer Faruk Batırel, Prof. Dr. Nurettin Bilici, Prof. Dr. Mehmet Tosuner, Prof. Dr. Fevzi Devrim ve Prof. Dr. Ahmet Kemal Çelebi; lisanüstü tezlerin tamamı değerlendirildiğinde en çok danışmanlık yapan öğretim üyelerinin Prof. Dr. Salim Ateş Oktar, Prof. Dr. Şükrü Kızılot, Prof. Dr. Kamil Tüğen, Prof. Dr. Zeynep Arıkan ve Yrd. Doç. Dr. Ahmet Bumin Doğrusöz olduğu tespit edilmiştir. Ayrıca 2003-2017 döneminde yüksek lisans tezlerine danışmanlık yapan öğretim üyelerinin ünvanlarının dağılımı \%30.6'sı Doç. Dr., \%34'ü Yrd. Doç. Dr., \%35.4'ü Prof. Dr. şeklinde iken ünvanların doktora tezlerindeki dağılımı ise \%9.9'u Yrd. Doç. Dr., \%15'i Doç. Dr. ve \%75.1'i de Prof. Dr. şeklindedir.

Yüksek Lisans tez savunmalarında en çok yer alan beş öğretim üyesi sırasıyla, Prof. Dr. Salim Ateş Oktar, Prof. Dr. Elif Sonsuzoğlu, Prof. Dr. Nagihan Oktayer, Prof. Dr. Ibrahim Atilla Acar ve Yrd. Doç. Dr. Engin Can iken doktora savunmalarında jürilerde en çok Prof. Dr. Ayşegül Mutlu, Prof. Dr. Ömer Faruk Batırel, Prof. Dr. Ahmet Burçin Yereli, Prof. Dr. Nurettin Bilici, Prof. Dr. Gülsen Güneş ve Prof. Dr. Elif Sonsuzoğlu'nun yer aldığı görülmektedir. Ayrıca lisansüstü tez savunmalarının tamamı değerlendirildiğinde jürilerde en çok sırasıyla Prof. Dr. Salim Ateş Oktar, Prof. Dr. Elif Sonsuzoğlu, Prof. Dr. Ahmet Burçin Yereli, Prof. Dr. Necmiddin Bağdadioğlu, Yrd. Doç. Dr. Ahmet Bumin Doğrusöz ve Prof. Dr. Zeynep Arıkan'ın yer aldığı görülmektedir.

Yüksek lisans ve doktora tezlerinin neredeyse tamamı "Maliye" ana bilim dalında yazıımıştır. Maliye ana bilim dalınan sonra sırasıyla "Mali Hukuk" ve "Maliye ve Ekonomi" ana bilim dalları gelmektedir. Bilim dalları incelendiğinde ise lisansüstü tezlerin bilim dalı dağılımında ilk dört sırada yer alan \%39.2 Mali Hukuk, \%30.6 Maliye, \%15.6 Maliye Teorisi ve \%9.3 Mali İktisat ön plana çıkmaktadır. Yüksek lisans tezlerinin bilim dalı dağılımında da ilk dört sırada \%40.5 Mali Hukuk, \%31.4 Maliye, \%14.8 Maliye Teorisi ve \%8.4 Mali iktisat yer almaktadır. Bilim dalı dağılımı doktora tezleri için \%33.3 Mali Hukuk, \%27 Maliye, \%19 Maliye Teorisi ve \%13.5 Mali İktisat şeklindedir.

Çalışmada analiz edilen lisansüstü tezlerin ağırlıklı olarak sırasıyla üç, dört ve beş bölümden oluştuğu görülmektedir. Bölüm sayıları genel olarak değerlendirildiğinde lisansüstü çalışmalarda en az bir bölüm en çok on bir bölüm olduğu, çalışmaların genel olarak üç bölümden oluştuğu, doktora tezlerinin en az iki en çok yedi bölümden oluştuğu görülmektedir. Ayrıca doktora tezlerinin yüksek lisans tezlerine kıyasla daha çok bölümden oluştuğu ifade edilebilir. Lisansüstü tezlerin sayfa sayısı incelendiğinde Yüksek Lisans tezlerinin ortalama 162 sayfa, doktora tezlerinin ortalama 288 sayfa ve lisansüstü tezlerin tamamının ise ortalama 187 sayfa olduğu belirlenmiştir. Maliye alanında son on beş yılda tamamlanmış tezlerden en az sayfa sayısına sahip Yüksek Lisans tezi 54 sayfa iken en çok 532 sayfadan oluşmaktadır. Doktora tezleri arasında ise en düşük sayfa sayısı 109 iken en yüksek sayfa sayısı 698'dir. Ayrıca Yüksek lisans tezlerinin daha çok sırasıyla 100-150 sayfa 150-200 sayfa, 200-250 sayfa arasında; doktora tezlerinin ise daha çok sırasıyla 250-300 sayfa, 200-250 sayfa, 300-350 sayfa, 150-200 sayfa, 350-400 sayfa arasında olduğu görülmektedir. 
Yüksek Lisans tezlerinde sırasıyla en çok "Vergi", "Avrupa Birliği", "Kayıtdışı Ekonomi", "Küreselleşme" ve "Etkinlik" anahtar kelimelerinin; doktora tezlerinde ise sırasıyla en çok "Maliye Politikası", "Küreselleşme", "Kamu Harcamaları" anahtar kelimelerinin kullanıldığı sonucuna varılmıştır. Lisansüstü tezlerin anahtar kelimelerinde en çok kullanılan beş kelime ise şunlardır: "Vergi", "Kamu", "Mali", "Avrupa", "Sosyal". Ayrıca lisansüstü tezlerin başlıklarında en çok kullanılan beş kelime "Vergi", "Türkiye'de", "Örneği”, "Değerlendirilmesi”, "Kamu” iken lisansüstü tezlerin özetlerinde en çok kullanılan beş kelime ise "Vergi", "Kamu", "Ekonomik", "Mali", "Sosyal" kelimeleridir.

Doktora tezlerinin yüksek lisans tezlerine kıyasla daha çok uygulama içerdiği, maliye alanında yazılan tezlerin özellikle son yıllarda uygulamaya yönelik olduğu, mali hukuk ana bilim dalındaki tezlerin sadece \%4'ünün uygulama içerdiği, lisansüstü tezlerde ampirik uygulama türlerinden en çok anket ve ekonometrik uygulamaların tercih edildiği, doktora tezlerinde ekonometrik çalışmaların yüksek lisans tezlerinde ise anket uygulamasının daha çok yer aldığı, maliye alanında ekonometrik analiz içeren tezlerde hem yüksek lisans hem de doktora tezlerinde daha çok zaman serisi analizinin kullanıldığı görülmektedir.

Maliye alanında son on beş yılda yazılmış 1714 lisansüstü tezin birçok değişken açısından kapsamlı bir şekilde analiz edildiği bu çalışma ile maliye alanında ileride yapılacak olan lisansüstü tezlerin çalışma konularının, içerik ve şekli unsurlarının belirlenmesinde araştırmacılara yol göstereceği düşünülmektedir.

Elde edilen bulgular dikkate alındığında maliye alanında lisansüstü eğitim almaları için kadınların teşvik edilmesi, alanda bilgiye erişimin sağlanması açısından lisansüstü tez yazarlarının tezlere erişim izni vermesinin sağlanması, ampirik uygulamaların önem kazandığı günümüzde maliye alanındaki tezlerin de ampirik uygulama içermesi açısından lisansüstü öğrencilerin yönlendirilmesi önerilebilir. Ayrıca bibliyometrik analizlerin yapılmasında veri sorunu yaşanmaması ve alana dair net bilgilerin elde edilebilmesi için bazı tezlerde ulaşılamayan yazarın özgeçmişi ve cinsiyeti, savunmada yer alan jüri üyeleri, ana bilim dalı ve bilim dalı gibi bilgilerin üniversitelerin tez yazım kılavuzlarına eklenerek tezlerde yer almasının zorunlu olması sağlanabilir. 


\section{Kaynakça}

Bayın, G. (2015). “Türkiye'de Sağlık Turizmi Alanında Yapılan Lisansüstü Tezlerin İçerik Değerlendirmesi", KMÜ Sosyal ve Ekonomik Araştırmalar Dergisi, Cilt:17(28), ss.49-55.

Bozdoğan, D. \& Bozdoğan, K. (2011). "Türkiye'de Maliye Alanında Yapılmış Akademik Çalışmaların Nicel Görünümü”, Ekonomi Bilimleri Dergisi, Cilt:3, No:1, ss.33-46.

Bozdoğan, D. (2010). Türkiye'de Maliye Alanında Yapılmış Akademik Çalışmaların Nicel Görünümü, Gaziosmanpaşa Üniversitesi Sosyal Bilimler Enstitüsü, (Yayımlanmamış Yüksek Lisans Tezi), Tokat.

Buttlar, L. (1999). "Information Sources in Library and Information Science Doctoral Research", Library and Information Science Research, Cilt:21, ss.227-245.

Coşkun, İ., Dündar, Ş. \& Parlak C. (2014). “Türkiye'de Özel Eğitim Alanında Yapılmış Lisansüstü Tezlerin Çeşitli Değiş̧kenler Açısından İncelenmesi (2008-2013)", Ege Eğitim Dergisi, Cilt:15(2), ss.375-396.

Edwards, S. (1999). "Citation Analysis as a Collection Development Tool: A Bibliometric Study of Polymer Science Theses and Dissertations", Serials Review, Cilt:25, ss.11-20.

Güçlü Nergiz, H. (2014). "Türkiye'de Lisansüstü Turizm Tezlerinin Bibliyometrik Profili (19902013)", VII. Lisansüstü Turizm Öğrencileri Araştırma Kongresi, 04-05 Nisan 2014, Kuşadası, Aydın.

Herubel, J-P.V.M. (1991). "Philosophy Dissertation Bibliographies and Citations in Serials Evaluation", Serials Librarian, Cilt:20, ss.65-73.

Karadağ, E. (2009). "Eğitim Bilimleri Alanında Yapılmış Doktora Tezlerinin Tematik Açıdan İncelemesi", Ahi Evran Üniversitesi Eğitim Fakültesi Dergisi, Cilt:10, Sayı:3, ss.75-87.

Kuyper-Rushing, L. (1999). "Identifying Uniform Core Journal Titles for Music Libraries: A Dissertation Citation Study", College and Research Libraries, Cilt:60, ss.153-163.

Sylvia, M. \& Lesher, M. (1995). "What Journals do Psychology Graduate Students Need? A Citation Analysis of Thesis References", College and Research Libraries, Cilt:56, ss.313318.

Şahin, M., Çetinoğlu, A. \& Ayvaz, S. (2013). "Türkiye'de Öğretmen Eğitiminin Tarihçesi İle İlgili Tezler Üzerine Bir Değerlendirme", Uluslararası Sosyal Araştırmalar Dergisi, Cilt:6(27), ss.494-504.

Şimşek, A., Özdamar, N., Uysal, Ö., Kobak, K., Berk, C., Kılıçer, T. \& Çiğdem, H. (2009). “ikibinli Yıllarda Türkiye'deki Eğitim Teknolojisi Araştırmalarında Gözlenen Eğilimler", Kuram ve Uygulamada Eğitim Bilimleri, Cilt:9(2), ss.941-966.

Tatlı, S. \& Adıgüzel, O. C. (2012). “Türkiye'deki Lisansüstü Karşılaştırmalı Eğitim Tezlerinin Çok Boyutlu Bir İncelemesi", Anadolu Üniversitesi Sosyal Bilimler Enstitüsü Dergisi, Cilt:12(1), ss.143-150.

Uçak, N. \& Al, U. (2009). "Bilimsel İletişimin Zamana Göre Değişimi: Bir Atıf Analizi Çalışması", Bilgi Dünyası, Cilt:10(1), ss.1-27. 
Walcott, R. (1991). "Characteristics Of Citations in Geoscience Doctoral Dissertations Accepted at United States Academic Institutions 1981-1985", Science and Technology Libraries, Cilt: 12(2), ss.5-16.

Walcott, R. (1994). "Local citation studies: A Shortcut to Local Knowledge", Science and Technology Libraries, Cilt:14(3), ss.1-14.

Waugh, C.K. \& Ruppel, M. (2004). “Citation Analysis of Dissertation, Thesis, and Research Paper References in Workforce Education and Development", Journal of Academic Librarianship, Cilt:30(4), ss.276-284.

Wehmeyer, J.M. \& Wehmeyer, S. (1999). "The Comparative Importance of Books: Clinical Psychology in the Health Sciences Library", Bulletin of the Medical Library Association, Cilt:87(2), ss.187-191.

Yorulmaz, B. (2016). “Türkiye'de Din Eğitimi Alanında Yapılan Lisansüstü Çalışmalar Hakkında Genel Bir Değerlendirme", Marmara Üniversitesi Öneri Dergisi, Cilt:12, Sayı:46, ss.4162.

Zipp, L.S. (1996). "Thesis and Dissertation Citations as Indicators of Faculty Research Use of University Library Journal Collections", Library Resources and Technical Services, Cilt:40, ss.335-342.

https://istatistik.yok.gov.tr/ Erişim Tarihi: 27.02.2017 